\title{
Hadimopanella from the Lower Cambrian of North Greenland: structure and affinities
}

\author{
SVEND E. BENDIX-ALMGREEN AND JOHN S. PEEL
}

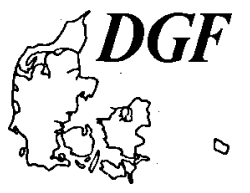

\begin{abstract}
Bendix-Almgreen, S. E. \& Peel, J. S.: Hadimopanella from the Lower Cambrian of North Greenland: structure and affinities. Bull. geol. Soc. Denmark, vol. 37, pp. 83-103. Copenhagen, October 14th, 1988. https://doi.org/10.37570/bgsd-1988-37-08

New records of minute phosphatic sclerites of Hadimopanella are described from the Aftenstjernesø and Henson Gletscher Formations of western and central North Greenland in strata of Early Cambrian age. The new material illustrates the occurrence of mineralisation in the wall between individual sclerites and confirms earlier suggestions of the close relationship between Hadimopanella and Utahphospha. Both forms are compared with spicules produced by living and fossil compound ascidians of the genus Cystodytes and it is concluded that they may have been Early Palaeozoic representatives of the chordate Class Urochordata.
\end{abstract}

S. E. Bendix-Almgreen, Geologisk Museum, Øster Voldgade 5-7, DK-1350 København K, Danmark. John S. Peel, Geological Survey of Greenland, Øster Voldgade 10, DK-1350 København K, Danmark. May 4th 1988.

In 1984 Peel \& Larsen documented the occurrence of microscopic phosphatic sclerites of Hadimopanella apicata Wrona, 1982 in samples of Lower Cambrian limestone from Nyeboe Land, western North Greenland (Fig. 1). This paper reports new discoveries of $H$. apicata from western and central North Greenland which serve to place the problematic microfossil within the known stratigraphic framework. Information is also presented concerning the nature of the body wall between individual sclerites, leading to comparison with the Cambrian and Ordovician microfossil Utahphospha Müller \& Miller, 1976 which was recently united with Hadimopanella in the Family Utahphosphidae by Wrona (1987). Finally, comparison of individual sclerites of $\mathrm{Ha}$ dimopanella with calcareous spicules present within the tunic of the compound ascidian Cystodytes leads to speculation concerning the possible chordate affinities of Hadimopanella and Utahphospha.

Gedik (1977, see also Gedik, 1981) introduced the genus Hadimopanella, with type species Hadimopanella oezgueli, for phosphatic sclerites of uncertain affinity from Middle (and ?Lower) Cambrian strata in Turkey. Bengtson (1977) gave a full description of similar material from the Lower Cambrian (Atdabanian) of Siberia under the name Lenargyrion knappologicum, but his new generic name was placed as a junior subjective synonym of Hadimopanella by Wrona (1982, p. 11) and van den Boogaard (1983, p. 337). Wrona (1982) described a new species from the Lower Cambrian of southern Spitsbergen as Hadimopanella apicata and this species was subsequently described by
Peel \& Larsen (1984) from strata of similar age in western North Greenland. Berg-Madsen (1985) illustrated a specimen of Hadimopanella from the Middle Cambrian of Balto-scandia while Gazdzicki \& Wrona (1986) figured a specimen assigned to Hadimopanella from blocks of Lower Cambrian carbonates within glacio-marine deposits in Antarctica. Wrona (1987) has subsequently described this material as Hadimopanella antarctica $n$. sp. Hinz (1987) described a single sclerite assigned to Hadimopanella apicata from the Lower Cambrian of Comley, England. Märss (1988) described Hadimopanella collaris n. sp., and a new form, Kaimenella reticulata $n$. gen. n. sp., considered to be a close relative of Hadimopanella, from Cambrian-Ordovician boundary strata in Estonia. Märss also recorded Hadimopanella oezgueli from Middle Cambrian strata in southern Kirgizia.

Wrona (1987) proposed a new family, Utahphosphidae, to accomodate Hadimopanella and Utahphospha. This name is considered to have priority over the new family name Hadimopanellidae proposed by Märss (1988) to contain Hadimopanella and Kaimenella.

\section{Hadimopanella from Greenland}

Hadimopanella apicata Wrona, 1982 was first described from Greenland by Peel \& Larsen (1984) from isolated spot samples of Lower Cambrian carbonates in north-east Nyeboe Land, western North Greenland (Fig. 1). The samples yielded an associated fauna of Serrodiscus (not S. bellimarginatus as originally identified by Peel, 1974 and Dawes \& Peel, 1984), Calodiscus, Pelagiella, Latouchella, fragments of olenellid trilobites and inarticulate brachiopods.

Field work in these Cambrian outer shelf sequences in northern Nyeboe Land and other ar 


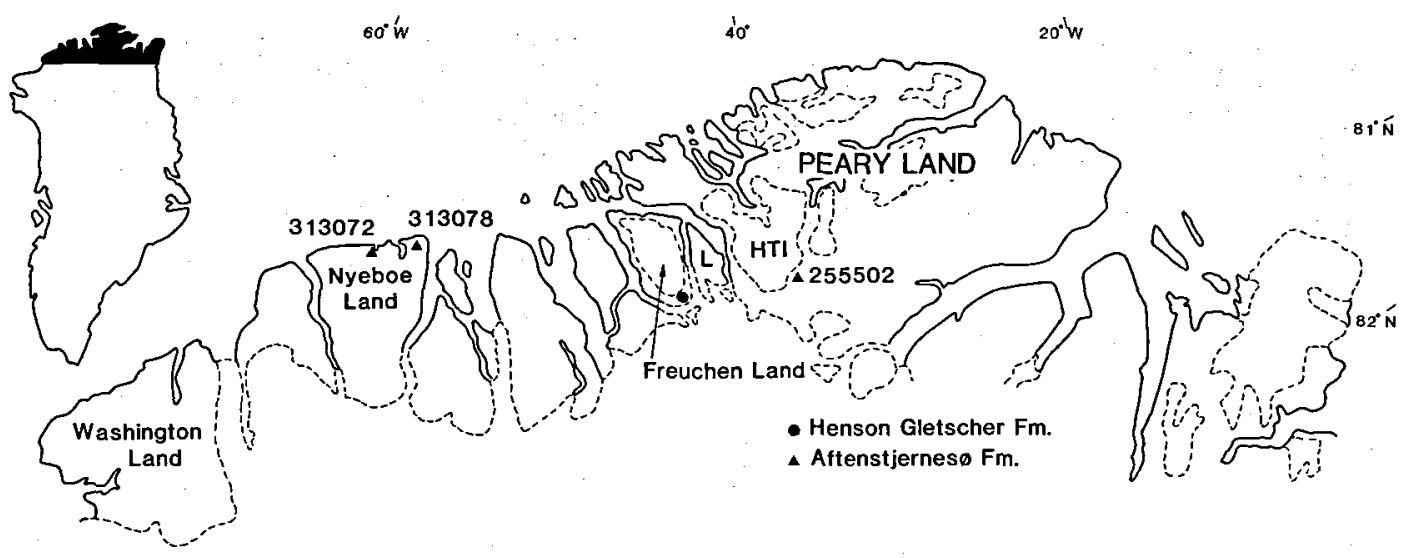

Fig. 1. Localities for Hadimopanella in North Greenland. HTI, Hans Tavsen Iskappe; L, Lauge Koch Land.

eas of central and western North Greenland undertaken during the North Greenland Project (1984-85) organised by the Geological Survey of Greenland (GGU; see Henriksen, 1987) has demonstrated that the limestones yielding Hadimopanella belong to the Aftenstjernes $\emptyset$ Formation (Fig. 2). This formation is the basal formation of the Brønlund Fjord Group of Early-Middle Cambrian age, originally described from more proximal shelf sequences in the southern Peary Land and southern Lauge Koch Land area (Fig. 1; Higgins et al., in press; Ineson \& Peel, 1987; in press). Hadimopanella apicata has subsequently been recovered in abundance from samples collected from sections measured through the Aftenstjernes $\emptyset$ Formation in northeastern Nyeboe Land by A. K. Higgins and N. J. Soper during 1984 (Fig. 1, GGU 313072, 313078). In addition, $H$. apicata has been located in the basal member of the Aftenstjernes $\emptyset$ Formation in southern Peary Land in samples col lected by Peter Frykman during 1979 (Fig. 1, GGU 255502). Sclerites of Hadimopanella from this locality are pale brown or amber in colour in contrast to the black specimens from Nyeboe Land.

Recently, dark sclerites of Hadimopanella apicata have also been recovered from samples collected by J. S. Peel and Mark R. Blaker from the lower part of the Henson Gletscher Formation in southern Freuchen Land (Figs 1,2). At this locality, the Henson Gletscher Formation is entirely of Early Cambrian age but the formation extends well into the Middle Cambrian in exposures around J. P. Koch Fjord and also in northern Nyeboe Land (Palmer \& Peel, 1979; Higgins et $a l .$, in press; Ineson \& Peel, in press). In southern Freuchen Land, $H$. apicata occurs in dark, bituminous carbonates yielding an abundance of trilobites and other microfossils (Blaker, 1986; Peel \& Blaker, 1988).

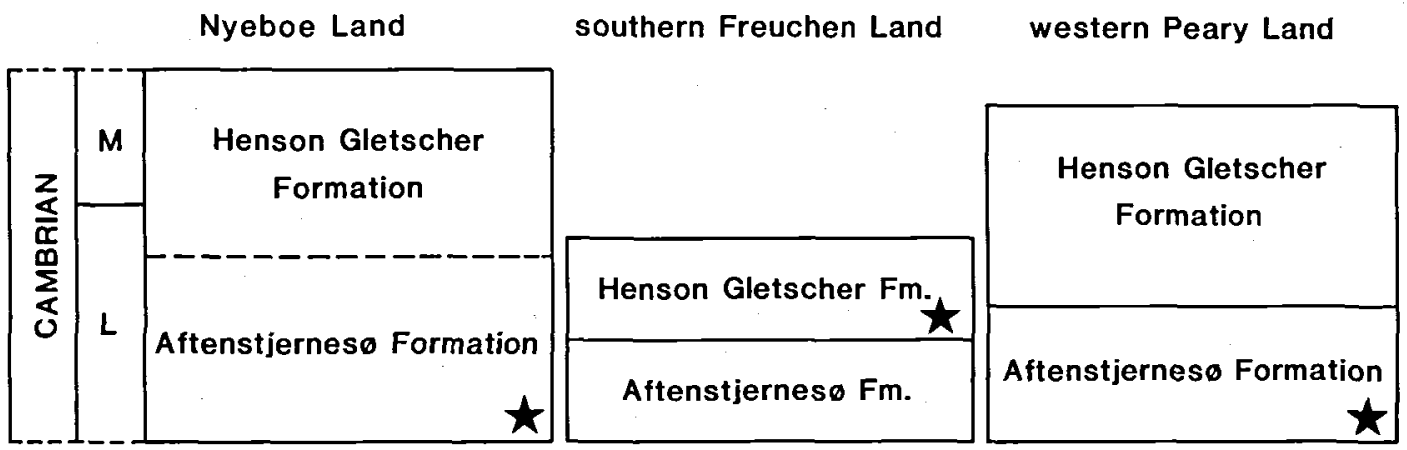

Fig. 2. Stratigraphy of Cambrian sequences in North Greenland yielding Hadimopanella (starred). 

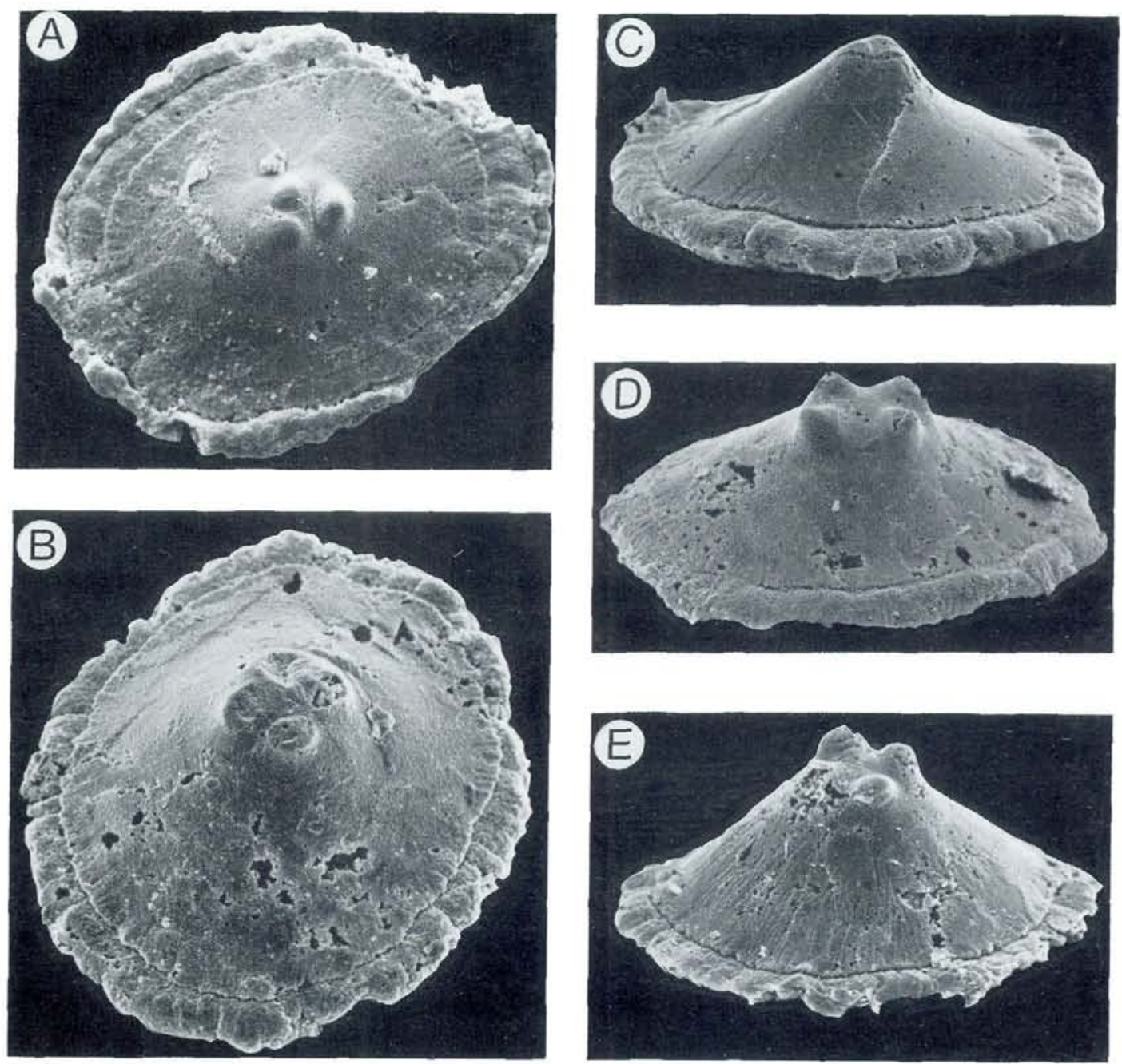

Fig. 3. Hadimopanella apicata Wrona, 1982. Aftenstjernesø Formation, Lower Cambrian, Nyeboe Land, Specimens from GGU sample 313072 . A, elongate sclerite with poorly preserved mineral matter around the periphery possibly representing mineralised inter-sclerite wall, MGUH 18.655, ×550; B, MGUH 18.656, ×750; C, MGUH 18.657, ×640; D, MGUH 18.658, ×710; E, MGUH $18.659, \times 700$.

\section{External morphology of Hadimopanella apicata}

The characteristic form of the circular to slightly elongate sclerites of Hadimopanella apicata, with the shallowly convex basal smooth face and the more elevated upper surface culminating in a central apex (Wrona, 1982; Peel \& Larsen, 1984), is well illustrated by the new material from Greenland (Fig. 3). The tendency reported by Peel \& Larsen for the central apex to show differentiation into two or more, commonly four, tubercles is also confirmed (Figs 3, $7 \mathrm{~B}, \mathrm{C}$ ).
An unusual sclerite from GGU sample 313078 (Aftenstjernes $\emptyset$ Formation in northern Nyeboe Land) is heavily overgrown by secondary phosphate deposition but shows spike-like tubercles developed on the upper surface at the junction between the capping layer and the brim (Fig. 4; the presence of possible apical tubercles can not be ascertained due to the mineral overgrowth). The cap and tubercles show a finely granular texture representing the equidimensional crosssection of crystallites elongated normal to the surface (Fig. 4D, E) while the brim exhibits the radial fibrous structure first illustrated by Wrona 

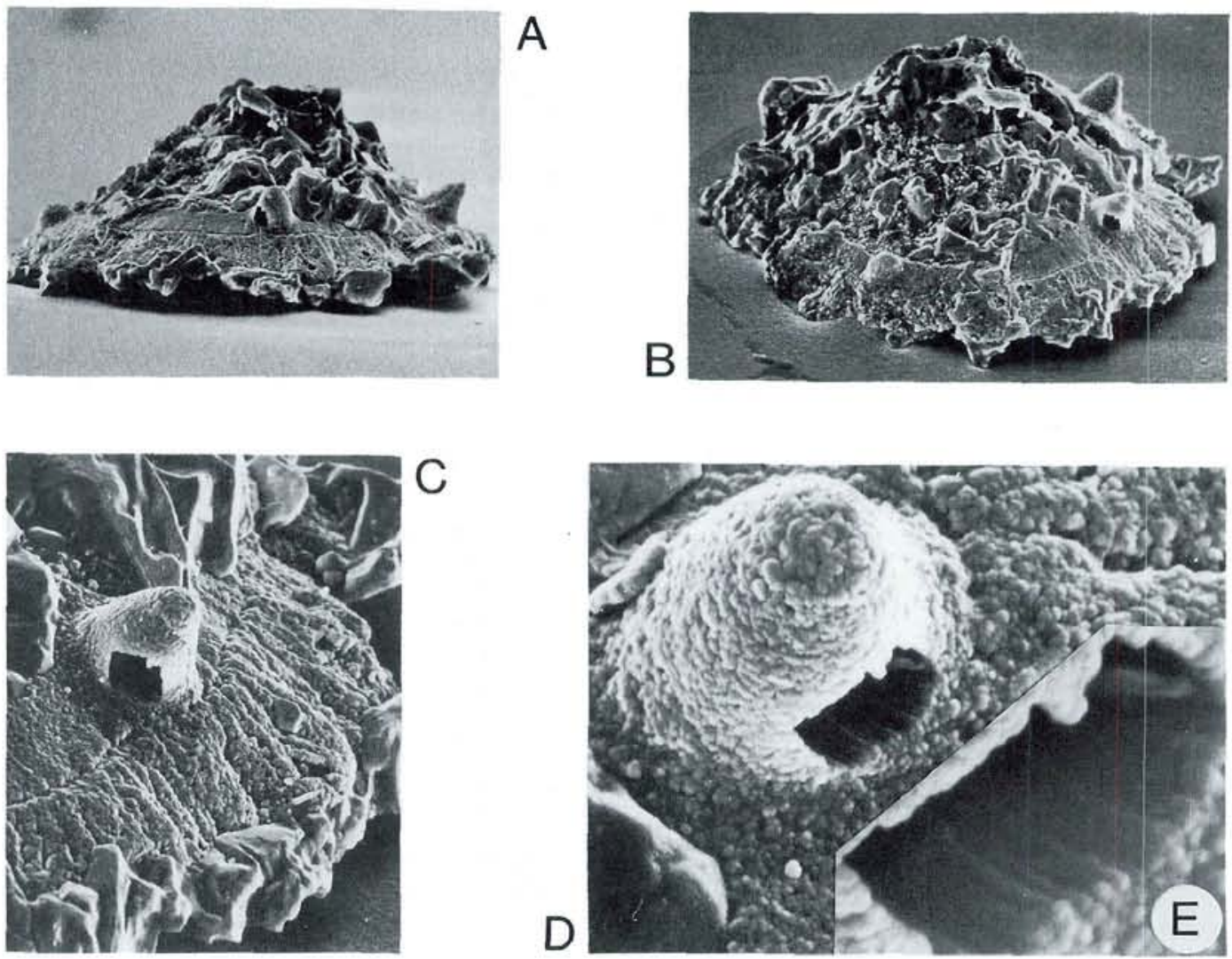

Fig. 4. Hadimopanella sp. Aftenstjernes $\emptyset$ Formation, Lower Cambrian, Nyeboe Land. Heavily mineral overgrown sclerite with prominent dispersed tubercles. MGUH 18.660 from GGU sample 313078. A, lateral view, $\times 575$; B, oblique lateral view, $\times 540 ; \mathrm{C}$. detail of a single tubercle and the fibrous brim, $\times 1500$; D, E, the same slightly damaged tubercle shown in $\mathrm{C}$ but enlarged to show the elongate crystallites, for discussion see text, $\times 4400$ and $\times 8800$, respectively.

(1982, pl. 1, fig. 5b) in which the fibrils apparently lie sub-parallel to the surface (Fig. 4C). In its distribution of tubercles this specimen is reminiscent of Hadimopanella antarctica Wrona, 1987 from limestone erratics of Early Cambrian age within the glacio-marine Cape Melville Formation of Early Miocene age from the Melville Peninsula of Antarctica described by Gazdzicki \& Wrona (1986, Wrona, 1987). The specimens show 9 to 13 peripheral tubercles and a single central tubercle. Their upper surface appears to be less vaulted than that of the Greenland specimen which also differs in having fewer peripheral tubercles (probably about 5 ).

Specimens from GGU sample 255502 (Aftenstjernesø Formation in southern Peary Land) tend to be larger and better preserved than the original material from GGU samples 83337 and 83338 illustrated by Peel \& Larsen (1984, figs 2-4) from northern Nyeboe Land (Figs 5, 6). They often lack the mineral overgrowth commonly seen in the latter material, in the new material from Nyeboe Land (e.g. GGU sample 313078) and also in the type suite from Spitsbergen illustrated by Wrona (1982, pls 1, 2).

\section{Mineralised inter-sclerite wall in Hadimopanella apicata}

The vast majority of the thousands of specimens of $H$. apicata preserved in the residue after acetic acid digestion of GGU sample 255502 are isolated sclerites. They are abundant in the sieved size fraction 45-75 $\mu \mathrm{m}$, infrequent in the 75-125 $\mu \mathrm{m}$ fraction and rare in the $125-250 \mu \mathrm{m}$ fraction. At magnifications between $\times 50$ and $\times 100$, most sclerites appear to have the characteristic smooth periphery in plan view but rare sclerites with a more jagged outline can be perceived. Exam- 
Fig. 5. Hadimopanella apicata Wrona, 1982. Aftenstjernesø Formation, Lower Cambrian, southern Peary Land.

MGUH 18.661 from GGU sample 255502 , a single sclerite with traces of the mineralised inter-sclerite wall. Lateral, oblique lateral and apical views, $\times 700$.
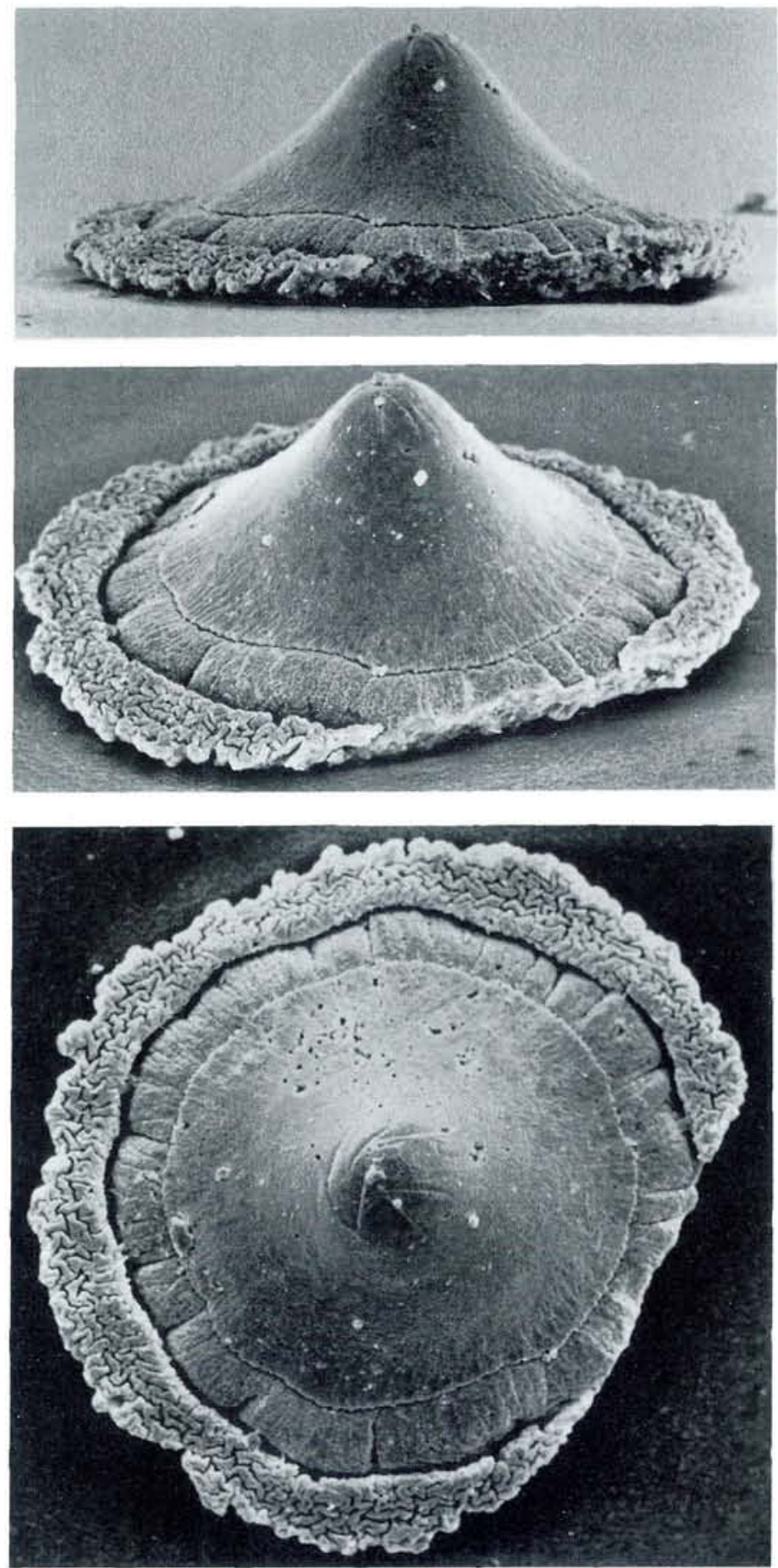

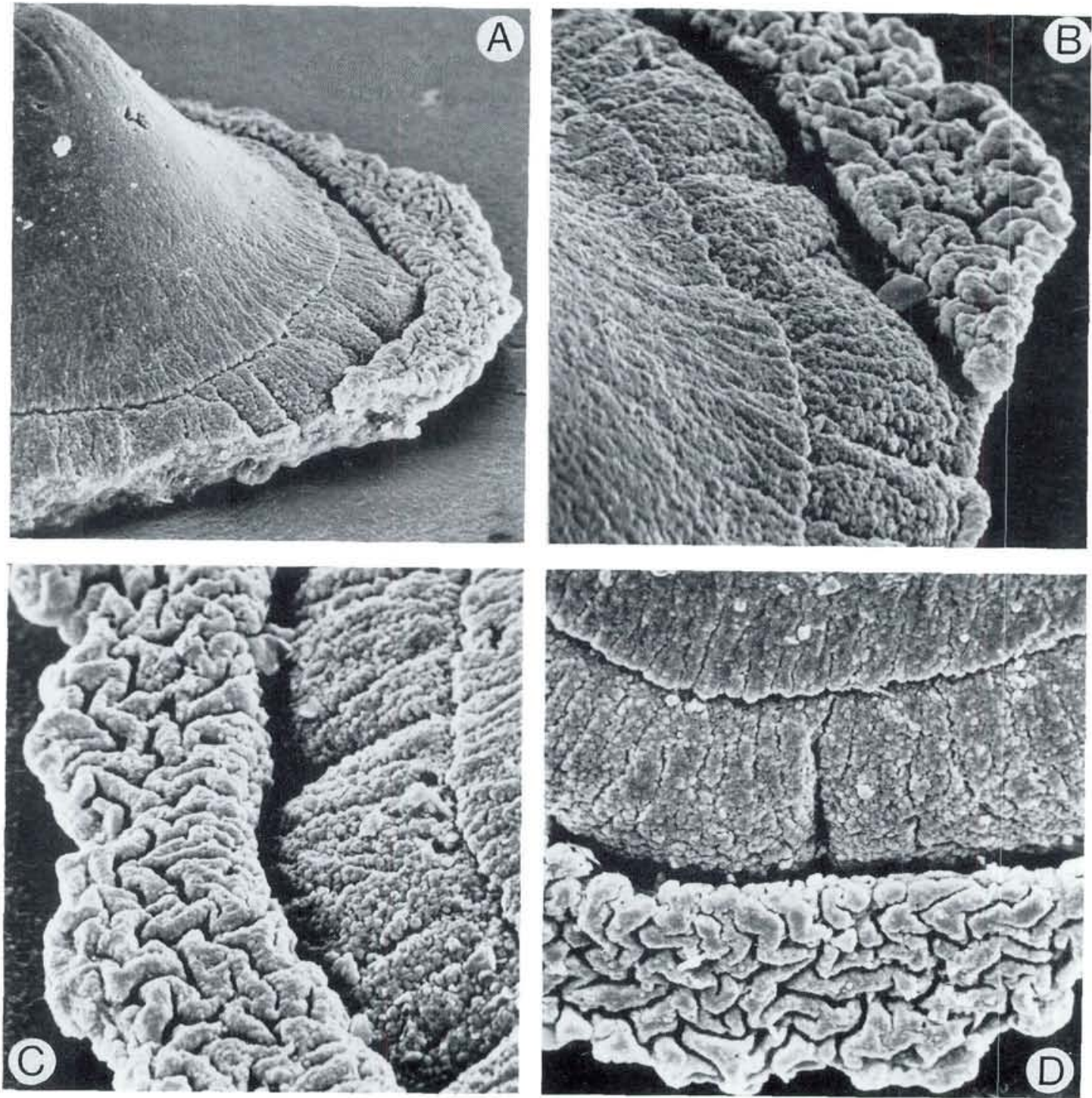

Fig. 6. Hadimopanella apicata Wrona, 1982. Aftenstjernesø Formation, Lower Cambrian, southern Peary Land. MGUH 18.661 from GGU 255502, details of the mineralised inter-sclerite wall in the specimen illustrated in Fig. 5. A, $\times 1125 ; \mathrm{B}, \mathrm{C}, \times 2800 ; \mathrm{D}, \times 2400$.

ination of one such sclerite by scanning electron microscopy has revealed that the irregular outline results from phosphatic material of a clearly organised nature (Figs 5,6). No doubt this represents accretion of a hard mineral substance during life in the soft tissue which constituted the wall supporting and separating the sclerites. The margin of this hard substance forming the inter-sclerite wall is raised slightly above the brim of the associated sclerite but a deep groove clearly delimits the sclerite from the inter-sclerite wall (Fig. 6). The impression is clearly that the sclerite is shal- lowly embedded within the inter-sclerite wall. The sclerite shows an undifferentiated apex and a well developed brim.

The most striking feature of the hard substance formed in the inter-sclerite wall is the structure of its upper surface. Convex ridges of relatively uniform width are separated by deep, narrow grooves. The ridges branch and are directionally not well organised, although there is an apparent tendency for ridges adjacent to the brim to be elongated radially and for those more distal to be parallel to the periphery. Apart from the obvi- 
ously damaged sector, the outer margin of this preserved belt of hard substance is not clearly fractured. At high magnification (Fig. 6C) the hard substance is seen to be composed of crystallites which are equidimensional in cross-section and of similar order of size to those forming the sclerite proper.

A single specimen from GGU 313072 shows traces of mineralisation around the periphery of the sclerite (Fig. 3A), but poor preservation inhibits its interpretation as mineralised inter-sclerite wall.

Märss (1988, p. 15) referred to a "mosaic pattern" on the marginal brim of sclerites of Hadimopanella collaris and also described "longitudinal dentated ribs" from the brim of the holotype of Kaimenella reticulata (Märss, 1988, p. 16). We are unable to determine on the basis of the published illustrations and descriptions whether or not these structures can be compared with the inter-sclerite wall described here in $H$. apicata.

\section{Histology of Hadimopanella sclerites}

A variety of randomly oriented sections of amber coloured sclerites from GGU sample 255502 was studied by means of ordinary and polarised light microscopy (Fig. 7). In addition to correspondence in histology to the conspecific material from Spitsbergen described by Wrona (1982), this examination confirmed that the Greenland material is also similar in all essential microstructural features to Hadimopanella knappologica and $H$. collaris as reported by Bengtson (1977) and Märss (1988), respectively. The descriptive terms of capping, core and smooth face used by Bengtson are adopted here.

The new material displays in some detail the fibrils noted by Wrona (1982); these are also present in $H$. collaris (see Märss, 1988) and $H$. knappologica, as indicated by the delicate canals shown by etched vertical transverse surfaces through the hard substance of the core illustrated by Bengtson (1977, figs 4A-D). The fibrils are largely of equal calibre and are arranged into two systems. Fibrils of one system extend downward sub-parallel to each other through the capping and the core to the smooth face from positions immediately below the outer surface of the dense capping. Fibrils forming the second system are radially disposed within the disc-like sclerites and roughly parallel to the upper surface of the core.

The fibrils probably made up a sizeable part of the total amount of organic material present in the core hard substance in the living state. Some indication of this is provided by the distribution of tube-like borings of invading micro-organisms which may have been fungi. These micro-organisms penetrated mainly along the course of the fibrils throughout the core hard substance and, in some cases, even into the denser material of the capping (Fig. 7). Some sectioned specimens show considerable activity by micro-organisms in the core hard substance immediately underneath the capping. Such activity may have resulted in greater susceptibility to etching which may explain the space between the capping and the core observed by Bengtson (1977, figs $4 \mathrm{~A}-\mathrm{C}$ ) in sclerites of $H$. knappologica.

There can be little doubt that during life the fibrils persisted in the peripheral parts of the core as tough structures which extended distally out from the brim and the smooth face into the soft tissue that supported and separated the sclerites. Points of exit of the fibrils are reported present on the smooth face of sclerites of Hadimopanella collaris (Märss, 1988, p. 13, pl. 3, fig. 7). Thus, the fibrils anchored the sclerites in fixed positions within the inter-sclerite wall, adding another analogy to those already noted by Bengtson (1977) between sclerites of Hadimopanella and lower vertebrate dermal skeletal elements, including odontodes (Ørvig, 1967, 1968, 1977). This similarity was first noted by Wrona (1982), elaborated upon by Dzik (1986) and commented by Märss (1988). However, the conditions displayed by the sclerites of Hadimopanella do not necessarily indicate that the fibrils were collagenous in nature, as believed by Dzik. No unambiguous evidence concerning fibril type was obtained from the optical microscopic survey of the Greenland material and any further consideration of their nature requires reliable information on ultrastructure from scanning electron microscopy.

The present study yielded little to qualify the observations recorded by Bengtson (1977) and Wrona (1982) with respect to the hard substance forming the core. None of the available sectioned sclerites shows any trace of the mineralised intersclerite wall discussed above (Figs 5,6). 

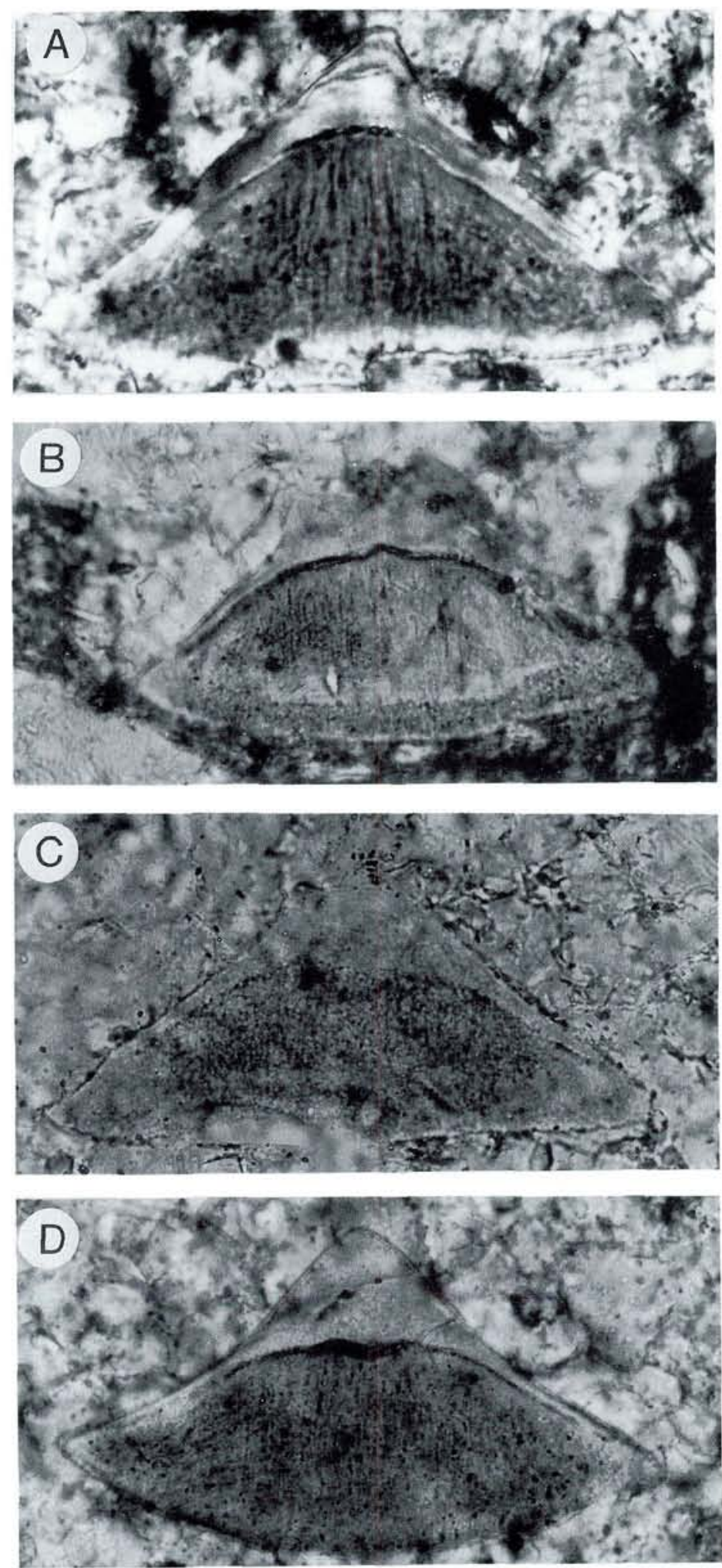

Fig. 7. Photomicrographs of polished thin sections of sclerites of Hadimopanella apicata Wrona, 1982. Aftenstjernesø Formation, Lower Cambrian, southern Peary Land. MGUH 18.662-18.667 from GGU sample 255502. Sections are oriented in a vertical transverse plane approximately through the centre of the sclerites (A-E, H) and in oblique transverse planes (F, G). B-F, approximately $\times 3000 ; A, G, H$, approximately $\times 5000$. The sectioned sclerites include two with several tubercles on the upper surface $(B, C)$. They display a system of downward extending fibrils crossed by fibrils of a radially directed system $(\mathrm{A}=\mathrm{E}, \mathrm{D}$, F-H). Numerous fine, irregular, tube-like borings from invading micro-organisms largely follow the course of the fibrils (A, B, E-H); they are widespread along the boundary between core and capping (A, C, D. $\mathrm{G}, \mathrm{H}$ ) but also penetrated upward into the denser capping hard substance (D, H). 

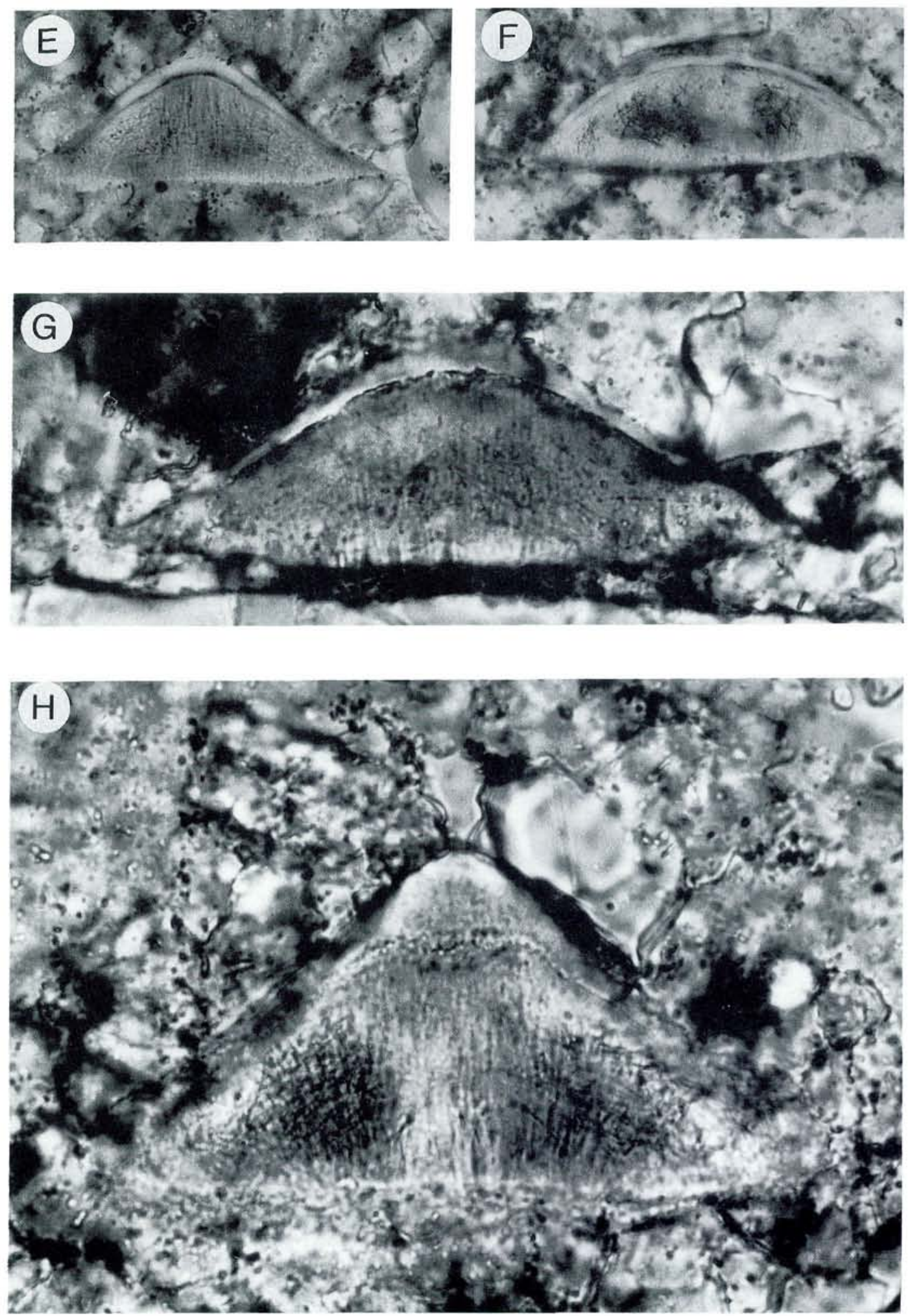

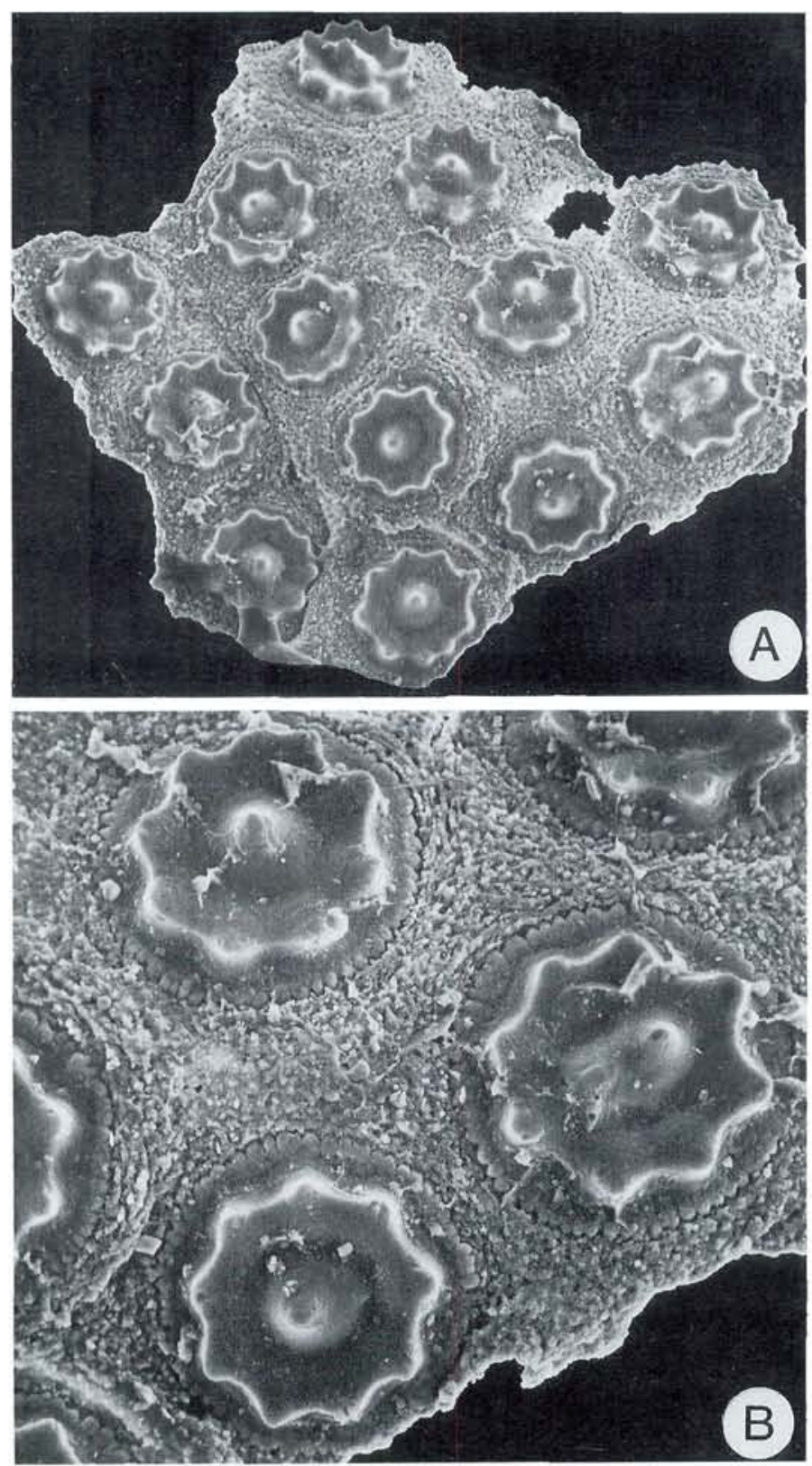

Fig. 8. Utahphospha cassiniana

Repetski, 1981. El Paso Group, Lower Ordovician, western Texas, U. S. A. USNM 292676, holotype. A, fragment with 13 sclerites surrounded by mineralised inter-sclerite wall, $\times 200 ; B$, detail of same, $\times 470$. Specimens figured by Repetski (1981, pl. 1, figs 1, 2. Copyright: Paleontological Society).

\section{Hadimopanella and Utahphospha}

Repetski (1981), in describing a new species of Utahphospha Müller \& Miller, 1976 from the Lower Ordovician El Paso Group in western Texas, suggested a close similarity between Utahphospha and Hadimopanella. He figured fragments of Utahphospha cassiniana Repetski, 1981 in which individual sclerites (termed "sequins"), varying in size from about $70-90 \mu \mathrm{m}$, are separated laterally by adjacent, mineralised intersclerite wall material (Figs 8, 9). Sclerites are strongly ornamented, principally with marginal tubercles and a central apex. Their resemblance to Hadimopanella in gross form is apparent, although none of the specimens of the latter genus illustrated by Gedik (1977, 1981), Bengtson (1977), Wrona (1982; 1987), van den Boogaard 
Fig. 9. Utahphospha cassiniana Repetski, 1981. El Paso Group, Lower Ordovician, western Texas, U. S. A. USNM 292676, holotype. A, detail of individual sclerite, $\times 1000$; $B$, detail of the mineralised inter-sclerite wall, X 1100. Specimens figured by Repetski (1981, pl. 1, figs 3, 4 . Copyright: Paleontological Society).
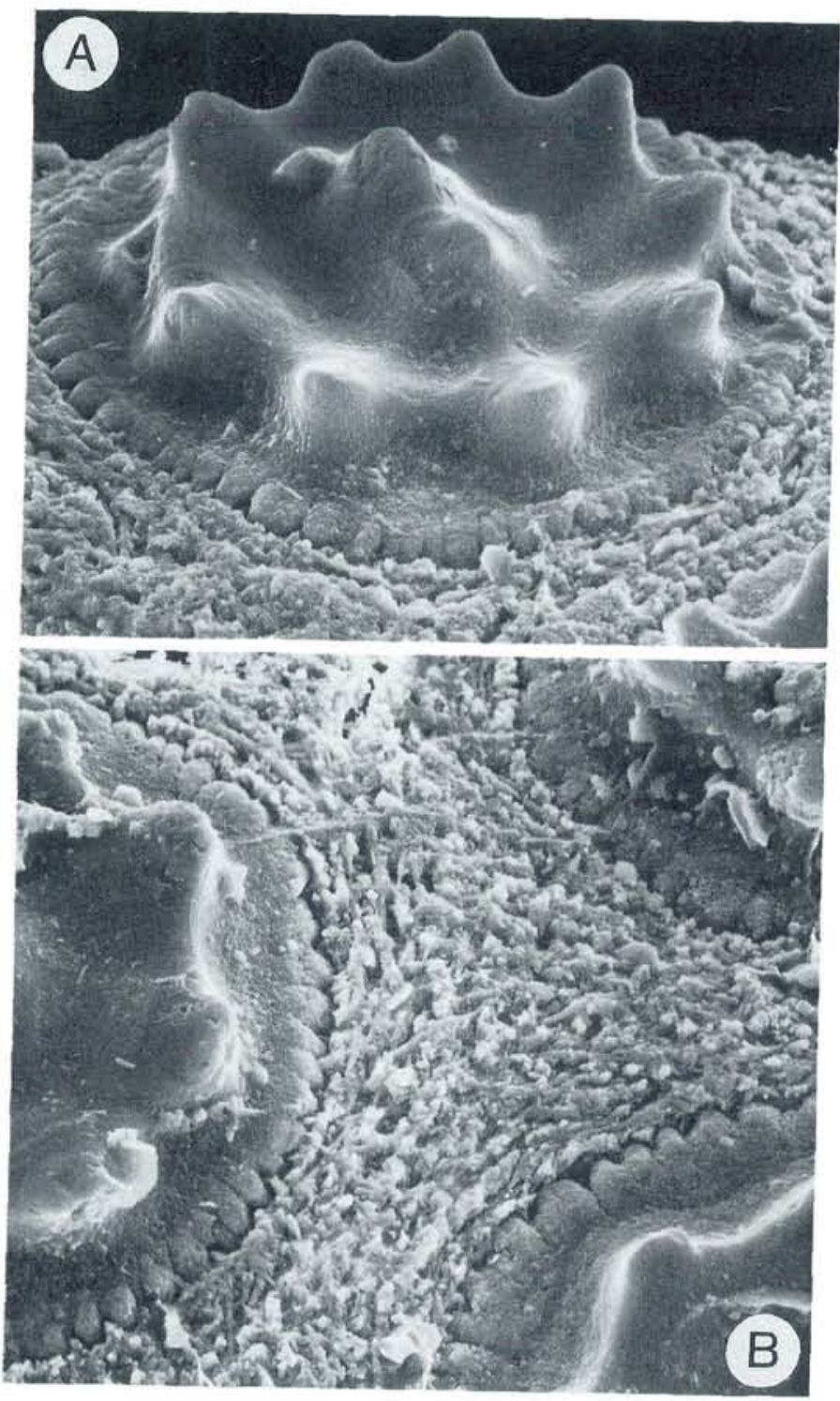

(1983), Peel \& Larsen (1984) or herein show closely similar tubercle patterns. For this reason we maintain Utahphospha and Hadimopanella as separate genera despite the suggestion by Repetski $(1981$, p. 397) that the latter may be a junior synonym of the former. This procedure is similar to that recently proposed by Wrona (1987) while erecting the Family Utahphosphidae.

The close relationship between Hadimopanella and Utahphospha cassiniana is emphasised by comparing the inter-sclerite wall material in the two forms. While not preserved to the same degree in $H$. apicata as in $U$. cassiniana, the simi- larity is striking (Figs 5, 6, 8, 9). The surface structure of the inter-sclerite wall is more perfectly preserved in $H$. apicata while in $U$. cassiniana there is some suggestion of a coarser degree of crystallisation, perhaps due to partial recrystallisation or mineral overgrowth (Figs 8, 9).

Wrona (1987, fig. 4) described three associations of sclerites of Hadimopanella antarctica which he believed to represent fragments of a larger test (Wrona used the term 'armour'). Up to about 12 sclerites of varying size lie essentially within a single plane and with their tuberculate capping oriented in the same direction. No trace 


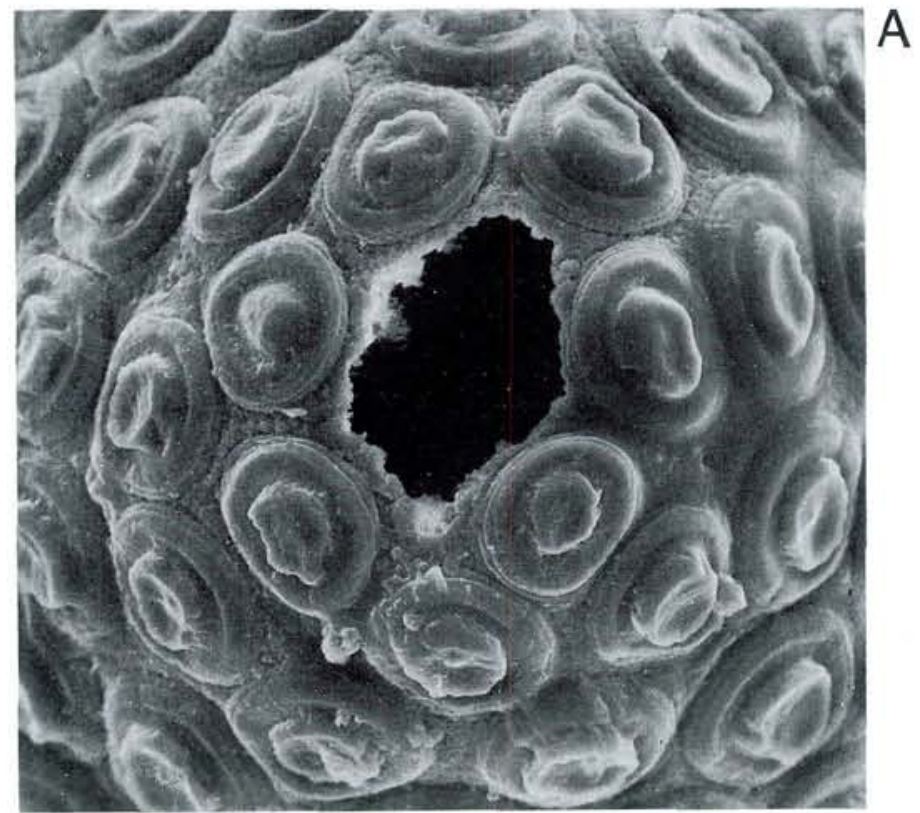

Fig. 10. Utahphospha sequina Müller \& Miller, 1976. Orr Formation, Upper Cambrian, Utah, U. S. A. UB 587, holotype. A, detail of the apex of the cone showing sclerites separated by mineralised inter-sclerite wall and the central perforation, $\times 370$. B, C, lateral and apical views of the cone, $\times 150$. Specimens illustrated by Müller \& Miller (1976, fig. 1. Copyright: Lethaia Foundation).

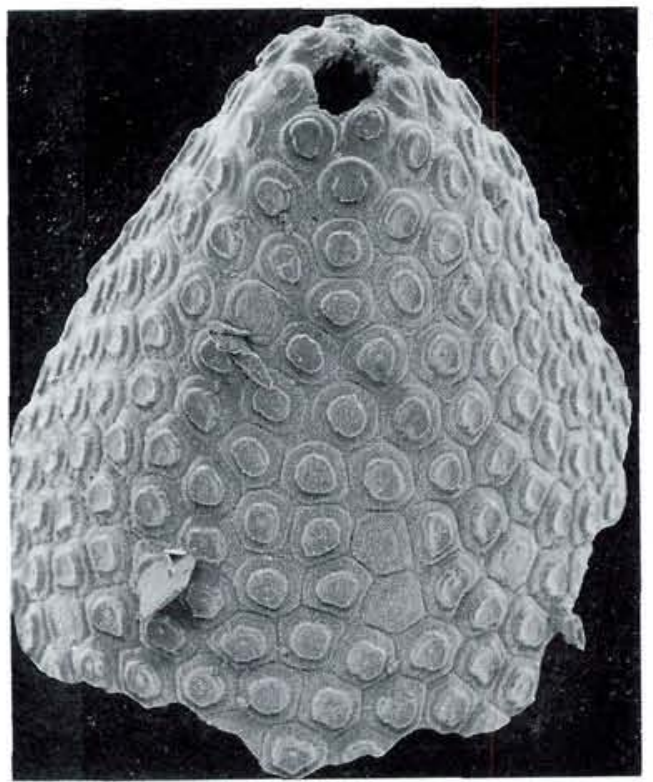

of mineralised inter-sclerite wall is preserved in H. antarctica. Wrona (1987, p. 42) used this character to delimit Hadimopanella from Utahphospha where the the inter-sclerite wall mineralisation is well developed.

The fragments of $U$. cassiniana figured by $\mathrm{Re}-$ petski (1981) give little information concerning the form of the complete animal. However, the type species of Utahphospha (U. sequina Müller

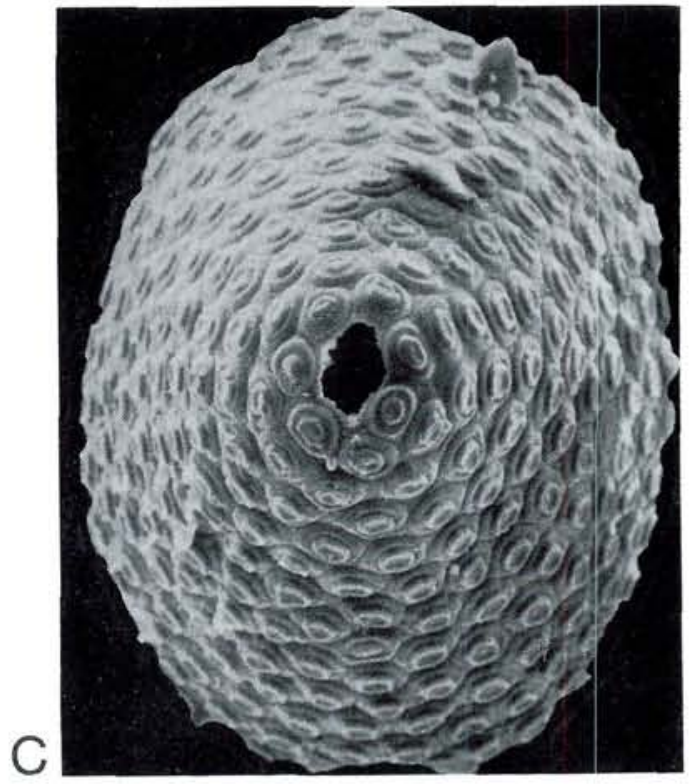

\& Miller, 1976 from the Upper Cambrian of Utah and Nevada) is known from hollow phosphatic cones (height about $500 \mu \mathrm{m}$, diameter of base about $100-500 \mu \mathrm{m}$ ) which are perforated at the apex; all known specimens are broken abapically (Fig. 10). In comparing the two species of Utahphospha, Repetski noted that sclerites in $U$. sequina tend to be polygonal and in contact with each other; only near the apex of the cone are the 
sclerites circular and clearly separated by the hard substance of the inter-sclerite wall (Fig. 10A; see also Müller \& Miller, 1976, figs. 2A-C). $\mathrm{He}$ also noted that sclerites of both $U$. cassiniana and Hadimopanella have convex smooth faces in contrast to the shallowly concave faces of $U$. sequina (Müller \& Miller, 1976, figs 2A-C, 5A); concave smooth faces also occur in sclerites of $H$. collaris (Märss 1988).

According to Müller \& Miller (1976, p. 394), sclerites of $U$. sequina grew periodically by superficial apposition of new layers of the hard substance. Confirmation of this interpretation would mean that $U$. sequina differed fundamentally from Hadimopanella since the sclerites in the latter genus show no evidence of successive growth once they have acquired their shape and functional position, as already pointed out by Bengtson (1977). Thus, the suggestion made by Dzik (1986, p. 249) that the capping of Hadimopanella sclerites grew centrifugally lacks foundation. The Müller \& Miller interpretation is mainly based on their observation of an inclusion of a foreign particle in one of the sclerites of $U$. sequina investigated by scanning electron microscopy, but this is hardly convincing evidence. The inclusion is more likely to represent an intrusion deep into the soft tissue at a site where differentiation for sclerite formation subsequently occurred.

Judging from the sections figured by Müller \& Miller (1976, figs 2A-C), it is presumed that the apparent multi-layering displayed in particular by the hard substance of the capping reflects the distribution of fibrils. In sclerites of $U$. sequina, these fibrils seem to be organised into systems of greater complexity than in Hadimopanella.

\section{Hadimopanella and early vertebrates}

The phosphatic composition and form of the sclerites in Hadimopanella naturally promote comparison with early vertebrates.

Microprobe analysis of Hadimopanella by Bengtson (1977) indicated that the mineral constituent of the hard substance of both the capping and the core is a fluorapatite. This suggests an original composition of biological apatite, though also aragonite may be phosphatised during fossilisation; in fact more readily so than calcite (Bushinsky, 1935). However, even if the the present mineralogical composition was derived from original biological apatite, it is known that processes related to fossilisation commonly produce enrichment in fluorine (McConnell, 1979). Therefore, it is generally impossible to decide from data derived only from fossils from which species of apatite the conversion commenced. Accordingly, the original mineral constituent of Hadimopanella may have been carbonate-hydroxyapatite (dahllite), which is by far the major mineralogical constituent of vertebrate hard tissues such as bone, dentine and cartilage calcifications (McConnell, 1979). On the other hand, it may just as well have been carbonate-fluorapatite (francolite) which, in addition to its occurrence in certain vertebrate hard tissues (e.g. selachian tooth enameloid; Glas, 1962; S. E. Bendix-Almgreen \& B. S. Bang, unpublished data from extant and fossil material), also has a wide distribution among invertebrates. Among extant invertebrates, carbonate-fluorapatite is known to be a constituent of the calcified tissues of inarticulate brachiopods, certain crustaceans and some molluscs (Moss, 1968; Rhodes \& Bloxam, 1971; Lowenstam, 1980; Jope, 1980).

In his discussion of Hadimopanella, Bengtson (1977) referred to Anatolepis Bockelie \& Fortey, 1976 , originally described as the geologically earliest vertebrate, but currently subject to debate in the literature concerning its true affinities (Bockelie \& Fortey, 1976; Peel, 1979; Thompson \& Plotnick, 1981; Briggs \& Fortey, 1982). However, comparison of Hadimopanella and Anatolepis reveals little morphological similarity. The pseudo-scale ornamentation of Anatolepis is an integral part of the outer layer of the plate-like fragments and spines unlike the discrete sclerites of Hadimopanella. Indeed, Hadimopanella is equally similar in this respect to the problematic phosphatic microfossil Mongolitubulus with which it occurs in the Henson Gletscher Formation in southern Freuchen Land (Peel \& Blaker, 1988) and which Missarzhevsky (1983) considered to be a primitive conodont.

\section{Hadimopanella as a vertebrate}

Bengtson (1977) found little convincing evidence that Hadimopanella was a vertebrate, remarking that there was a strong possibility that the scle- 
rites originated in an unknown group of invertebrates. Wrona (1982, pp. 9, 13-14), on the other hand, was of the opinion that these "microfossils resemble dermal sclerites of primitive vertebrates". This opinion was adopted by Dzik (1986, pp. 250-251, fig. 8) who attempted to show that Hadimopanella and Utahphospha phylogenetically are linked intimately with early vertebrates. He maintained that sclerites of Hadimopanella resemble in terms of shape "...dermal tubercles of Astraspis [which] have an enamel (sic) microstructure that is similar to that of...Hadimopanella".

In terms of shape, it is clear that the disc-like Hadimopanella sclerites differ markedly even in gross morphology from the radially-ridged, mushroom-like dermal tubercles situated superficially on the thick exoskeletal plates of Astraspis (Ørvig, 1958, fig. 4, pl. 1, figs $1-2,4$ ); the same is the case also with respect to the tubercles occurring on the plates and scales of Eriptychius ( $\emptyset_{\mathrm{r}-}$ vig, 1958, fig. 5; Denison, 1967).

The abraded apex of many sclerites of Hadimopanella and the systems of fibrils, discussed above, indicate that the sclerites occupied superficial positions in a supporting and surrounding soft tissue, the inter-sclerite wall. They were here firmly anchored beside each other. In these respects the sclerites are reminiscent of the scale covering of early vertebrates such as, for example, the thelodonts, which probably have remained at a primary micromeric stage of dermal skeletal development (Ørvig, 1968). However, there is no evidence to suggest that the similarity reflects anything other than simple analogy.

With regard to minute structural features, it is significant that Hadimopanella sclerites entirely lack anything equivalent to the 'pulp' cavity present, for example, in thelodont scales and in the tubercles of Astraspis dermal elements. Nor is there anything resembling the branching vascular canals of the ornamental tubercles and ridges of the dermal plates and scales of Eriptychius (Bryant, 1936; Ørvig, 1958, 1965, 1967; Denison, 1967; Gross, 1967). Moreover, there is no evidence to suggest that sclerites of Hadimopanella developed ontogenetically in close proximity to any system of nutritive vessels like those enclosed in the complex vascular canal system meandering throughout the dermal skeletal elements of, for example, Astraspis and Eriptychius. The "spongy internal structure" of sclerites of Kaimenella reticulata (Märss, 1988, p. 14) is perhaps reminiscent of conditions in the dermal skeletal elements of Astraspis and certain other early vertebrates. The nature of the histological constituents of the hard substances of the sclerites remain to be clarified, however, both relative to the early vertebrates and to Hadimopanella. Kaimenella reticulata, which to some extent resembles the Middle Ordovician Milaculum ethinclarci (Märss, 1988, p. 13), is therefore not considered further in this paper.

As regards the histological structure of the hard substance of the capping and the core of Hadimopanella, the significant lack of anything which could represent lacunae from scleroblasts or scleroblast processes (e.g. dentine tubuli) has already been remarked upon by Bengtson (1977). It is also significant to note that, in the living state, the comparatively dense hard substance of the capping contained quite coarse fibrils and that it was susceptible to penetration by microorganisms, as noted above. These features indicate unequivocally that the hard substance forming the capping of Hadimopanella can not possibly qualify as any sort of enameloid or, for that matter, enamel as claimed by Dzik (1986). The same conclusion is indicated by the crystallite structure (Fig. 4D, E). The large, straight and elongate crystallites show a regular arrangement, almost like tidily stacked logs. This is structurally entirely different from the fibre-bundle images (Ørvig, 1976) characteristic of the ultrastructure of genuine hypermineralised hard substances, including enameloid of the sort present in Astras$p i s$, where the fibre-bundle images are formed by randomly oriented crystallites (Reif, 1979; Dzik, 1986). Nor is there any similarity with those fibrebundle images which distinguish the structural types of enameloids referred to as radial paralleltextured acrodin of actinopterygians and coronoïn of elasmobranch teeth (Ørvig, 1978; Bendix-Almgreen, 1983).

Finally, we agree with Bengtson (1977, p. 760) that not even the hard substance of the core of Hadimopanella seems "to offer...striking points of comparison..." with "...the rare examples of acellular bone tissue in vertebrates (e.g. aspidin in heterostracans)." Neither the histology nor the ultrastructure support interpretation of this hard substance as any likely phylogenetic precursor of 
vertebrate hard tissues, including aspidin or dentines, in the manner suggested by Wrona (1982, p. 14).

In summary, the above comparison does not sustain any hypothesis that Hadimopanella pertains to, or can be among the direct phylogentic predecessors of, the early vertebrates. On the other hand, this does not exclude the possibility that Hadimopanella and Utahphospha could be early representatives of another major group within the chordate stock.

\section{Hadimopanella as a primitive chordate}

The sclerites of Hadimopanella (and the ones fused into the compound plates and cones of Utahphospha) are dermal skeletal units which did not grow subsequent to their original formation. All features of shape, size and microstructure were acquired exclusively during the ontogenetic formation of each individual sclerite. This formation can hardly have taken place anywhere else than in soft tissue within the inter-sclerite wall, immediately below the surface and at the same site where the sclerites subsequently emerged fully formed and firmly anchored in their functional positions. During their functional life the sclerites were evidently partially exposed superficially and may have acted in some form of protective role, probably entirely inactive, merely providing resistance against various sorts of predation and abrasion.

On the basis of this interpretation, it can be assumed that each individual sclerite formed ontogenetically out of a single undivided papillalike structure which was bounded by an adjoining layer of specially differentiated epithelial cells. The deduced initial stages of sclerite formation may appear similar to the initial stages in the formation of odontodes and teeth in lower vertebrates (see Ørvig, 1977). However, the properties of the hard substances of the sclerite and other evidence suggest significant differences. For example, mesenchymatically derived scleroblasts were probably never present. There is no evidence that such scleroblasts participated during hard substance mineralisation, or during the preceeding ontogenetic stages when organic matrix was synthesised. As in many invertebrates, the constituent compounds of the organic matrix in the papilla-like structures may have been produced entirely by ectodermal cells and the subsequent mineralisation may have depended exclusively on the activities of the adjoining epithelial cells. The differences in density between the hard substances forming the capping and the core seem to be in accord with such an assumption.

To a large extent, these conditions of sclerite formation are paralleled by calcified hard tissue ontogeny in many invertebrates. In those invertebrates in which the calcified hard tissues are of ectodermal origin, the calcified tissues are "derived from the activity of epithelial cells whose cytomorphological differentiations during this process are strikingly similar to those noted in vertebrate amelogenesis" (Moss, 1968, p. 362). In this latter term Moss also includes enameloid histogeneses that have been reviewed by $\emptyset$ rvig (1978; 1980, p. 234) and Bendix-Almgreen (1983).

It is of particular interest in the context of Hadimopanella to note that the chordate Class Ascidiacea (the sea squirts) includes a range of species which in their mantle or tunic (hence the common name tunicates) possess sclerites (generally referred to as spicules), which are formed ontogenetically by ectodermal cell activity. Organic matrix compounds are also known to be involved in the processes of spicule formation (Lafargue \& Kniprath, 1978; Lambert, 1979).

Ascidian spicules often appear in the form of stellate units about $30-80 \mu \mathrm{m}$ in diameter; in the comparatively few cases where such spicules have been more closely investigated, they have been found to consist of aragonite or vaterite (Schmidt, 1924; Lowenstam \& Abbott, 1975; see also Lafargue \& Kniprath, 1978). The spicules thus have the potential for fossilisation and have been described from Tertiary strata (e.g. Monniot \& Buge, 1971).

The compound ascidian genus Cystodytes von Drasche, 1884 is also represented by fossil material. In this genus the many individuals comprising the colony are contained within a common tunic. Cystodytes develops large numbers of spicules but seems to differ from the majority of other spicule-bearing ascidians in that the spicules are concentrated in a spicular sack surrounding each individual zooid (Lambert, 1979). The spicules in Cystodytes have been illustrated 


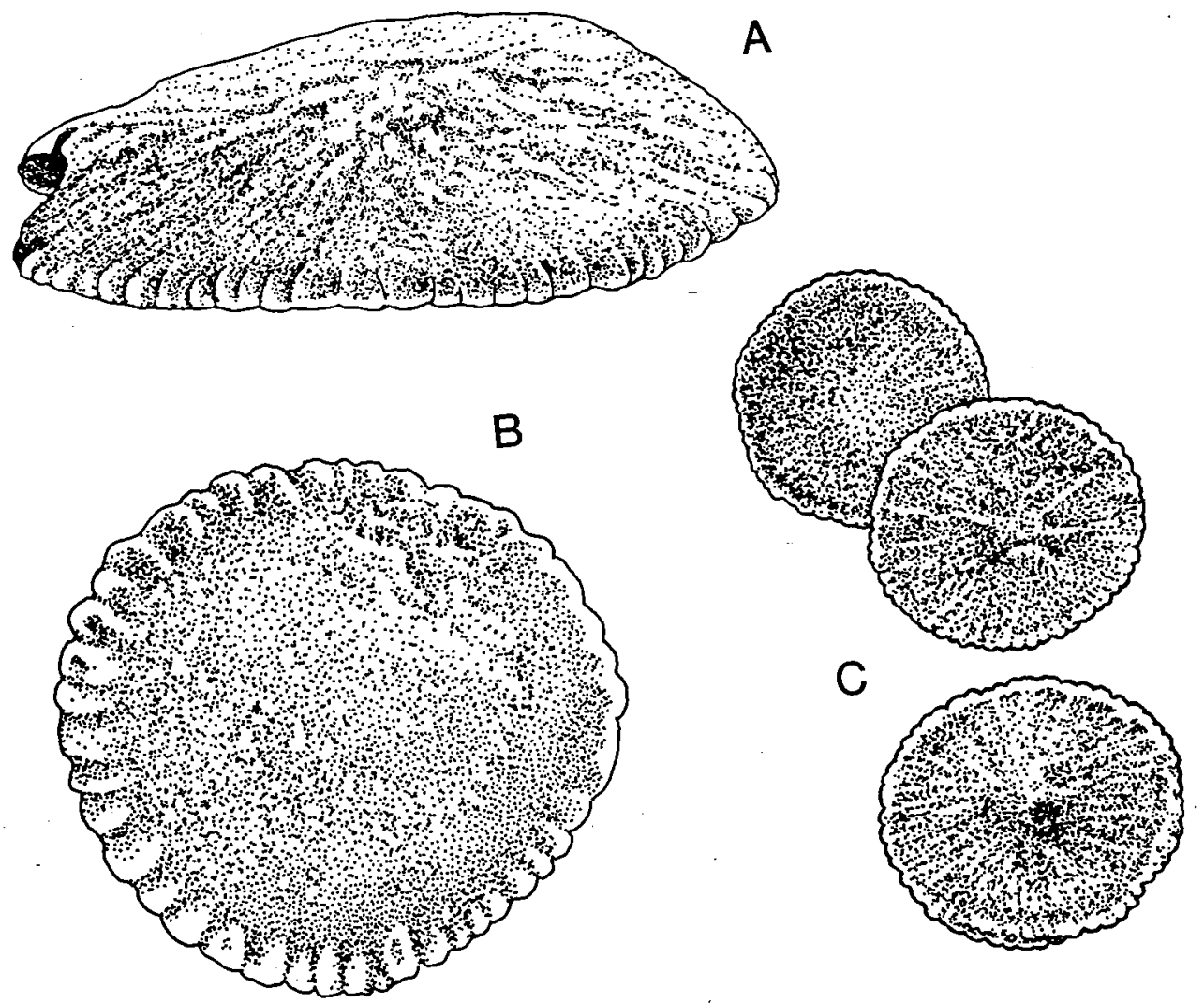

Fig. 11. Spicules of living species of Cystodytes von Drasche, 1884, drawn from the excellent stereoscan micrographs of Monniot \& Buge (1971). A, Cystodytes senegalense, $\times 600 ; \mathrm{B}$, Cystodytes guinensis, $\times 90 ; \mathrm{C}$, Cystodytes senegalense, $\times$ about 140 . Note the marginal tubercles and, in $C$. senegalense $(A, C)$, the radial structure on the arched upper surface.

by many writers (Van Name, 1921; Brien, 1948; Huus et al., 1956; Monniot, 1970; Monniot \& Buge, 1971; Lambert, 1979) and they are unusual in that many show a striking morphological resemblance to the individual sclerites of Hadimopanella apicata (Fig. 11).

Lambert (1979) has demonstrated that the spicules in Cystodytes lobatus (Ritter, 1900) are formed in the innermost layer of the tunic (the 'tunic spicular lamina') which lines the cavity occupied by each individual zooid, but is separated from the abdomen of the zooid. The spicules are closely spaced and overlap each other within the tunic spicular lamina, but they are not in contact (Fig. 12). They lie with their flattened surfaces parallel to the abdominal wall, although this pattern may be disturbed during budding (Lambert, 1979). Lambert commented that spicules are added continuously as young zooids grow and that older spicules increase in diameter during growth. She noted that spicules in adult colonies may be $1 \mathrm{~mm}$ or more in diameter and develop tubercles; a figured specimen almost $400 \mu \mathrm{m}$ in diameter (Lambert, 1979, fig. 11) shows a dense pattern of peripheral tubercles of similar relative size, but much more closely spaced, to those seen in Hadimopanella antarctica Wrona, 1987 and the specimen of Hadimopanella illustrated in Fig. 4. Similar peripheral tubercles are seen in the fossil spicules illustrated by Monniot \& Buge (1971, pl. C, D; see also Fig. 11).

The similarities just mentioned may suggest that Hadimopanella sclerites could be derived from an early ascidian, although such a form would hardly have been a close relative of the fossil and extant species of Cystodytes. Several conspicuous points of difference preclude such a close relationship to Cystodytes; some of these will be more closely considered below.

Spicules have been reported from ascidian genera belonging to the families Polycitiridae, Didemnidae, Ascidiidae, Pyuridae and Molgulidae; 
Fig. 12 A. Camera lucida sketch of an oblique section through a colony of Cystodytes lobatus (Ritter, 1900) showing the organisation of calcareous spicules (black) around the zooid cavities within the tunic (upper and lower surfaces indicated). Solid lines indicate the margins of individual zooid cavities which are depressions in the drawn surface; zooids remaining in position are stippled. Spicules lie with their flattened surfaces parallel to the wall of the zooid cavities and thus appear lenticular in cross-section (a) or circular when seen in plan view (b). Variation of spicule shape in the sketch thus reflects orientation of the spicules within the translucent tunic. B, schematic section $(X-Y)$ through $A$ showing the distribution of spicules around the zooid cavities. Length of bar $=1 \mathrm{~mm}$.
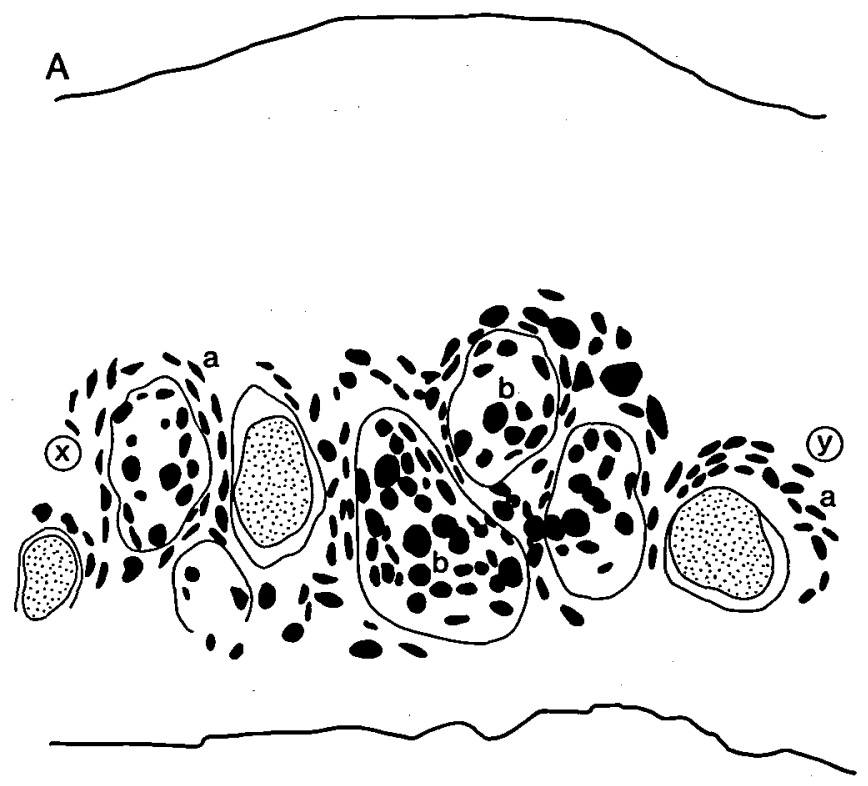

B

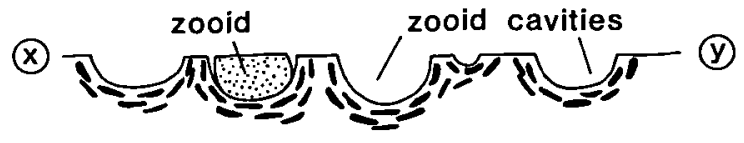

though mainly stellate they show considerable variation in shape - disc-like (as in Cystodytes), tetrahedroniform, rod-like, needle-like, featherlike, etc. Apparently spicules also show considerable variation with respect to their topographic occurrence in the various species (see Huus et al., 1956). However, information in the literature regarding these aspects is generally vague, except in the study of Cystodytes lobatus made by Lambert (1979). It is as much for this reason as for the broad similarity in shape between the sclerites and spicules that the following closer comparison of the sclerites of Hadimopanella and Utahphospha with ascidian spicules is based mainly on conditions known from Cystodytes lobatus.

1. Spicules in Cystodytes lobatus and in the Didemnidae are ontogenetically formed by ectodermal cell activity and an organic matrix comprising sulphated mucopolysacharides (and probably other compounds) is implicated in the process (La- fargue \& Kniprath, 1978; Lambert, 1979, pp. 473-474; see also Mathews, 1975, p. 182). As has been noted above, there are good reasons to assume that the Hadimopanella and Utahphospha sclerites are also entirely of ectodermal origin.

2. As indicated by their behaviour during zooid budding, spicules of Cystodytes lobatus seem to occupy fairly fixed positions within the tunic spicular lamina (Lambert, 1979, p. 472). Also Hadimopanella sclerites, and no doubt those of Utahphospha too, occupied fixed positions, firmly anchored by complex fibril systems.

3. According to Lambert (1979, p. 472), "reallocation" of existing spicules in the newly established spicular sacks and synchronous "active and rapid synthesis of new spicules" occur subsequent to budding in C. lobatus. A similar ability to produce and add new sclerites during growth of the individual animal was in all probability also characteristic of the intersclerite wall in Hadimopanella, and probably also in juveniles of Utahphospha.

4. Spicules of Cystodytes lobatus can increase in size during their existence (Lambert, 1979), although the rate of growth may be expected to decelerate with increasing age. In contrast, sclerites of Hadimopanella and Utahphospha were clearly formed in their final shape and size at one time. However, they could subsequently 'grow' by secondary accretion of hard substance along their periphery in the inter-sclerite wall soft tissue. In the case of Utahphospha, this accretion caused fusion into larger compound structures. Thus, the inter-sclerite wall in 
these fossil forms had the capability of continuous formation of hard substance and, in this respect, appears to be similar to the tunic spicular lamina.

5. Sclerites of Hadimopanella and Utahphospha were located in superficial positions, while spicules of Cystodytes lobatus are situated in the innermost part of the tunic, adjacent to the individual zooids, namely the tunic spicular lamina.

The tunic spicular lamina is only a minor constituent part of the entire tunic. Externally to it the main portion of the thick tunic in Cystodytes lobatus is composed of numerous densely packed, large, acid-filled bladder cells which are separated from each other by what is generally referred to as tunic ground substance (Lambert, 1979, figs 9a-c). There can be little doubt that the acid-filled bladder cells are a highly specialised feature, the acquisition of which may have caused considerable reorganisation of the entire tunic structure. However, original structural constituents of the tunic would not necessarily have been lost with the acquisition of bladder cells and may still remain in a reduced state, serving a modified function. The tunic spicular lamina and its spicules are presumably remnant structures from the original tunic. Accordingly, spicules of Cystodytes lobatus may be the reduced remnants of ectodermal skeletal units which originally occupied superficial positions in the tunic reminiscent to those deduced for the sclerites of Hadimopanella and Utahphospha.

If the spicules of Cystodytes lobatus are largely remnant structures derived from units resembling the sclerites of $\mathrm{Hadi}$ mopanella, it is clear that their functional equivalents among extant forms would be found in the spiked, cuticle-covered papilla-like units studding the external surface of the solitary ascidian Halocynthia (see Smith, 1970, figs 4a, c; Stievenart, 1971, figs 1-3). These units have a globose base extending into an elongate spine; they mainly consist of superficially extending coarse fibrils. During growth of the animal new units are added to the external pattern in spaces between the existing ones. In both these features there appears to be close resemblance to the situation in Hadimopanella, although mineralised spicules do not seem to occur in conjunction with the ectodermally derived units in Halocynthia.

6. Mature spicules of Cystodytes lobatus and other species of the genus (Monniot, 1970) show no notable changes in structure from top to bottom. However, considering that the spicules may be remnant structures no longer serving their original function, this difference from Hadimopanella is possibly in significant.

7. In those cases where spicules of extant ascidians have been subject to closer investigation they have been shown to consist of aragonite or vaterite (Schmidt, 1924; Lowenstam \& Abbott, 1975; see also Lafargue \& Kniprath, 1978). Accordingly, they differ from the sclerites of Hadimopanella and Utahphospha which consist of fluorapatite in the fossil state, probably reflecting an original phosphatic composition. This compositional difference, however, may not rule out Hadimopanella and Utahphospha as possible early ascidians. The differences could be cited in support of the thesis of Lowenstam $(1980$, p. 13) that "phosphate hard parts are found in a greater diversity of higher taxa in Cambrian deposits than in younger Phanerozoic rocks..." and that "...the progression of substituting carbonate minerals for phosphates in many groups of organisms is the most fundamental evolutionary trend in hard part development so far in evidence." It remains to be established whether or not this thesis is tenable.

Although many of the lines of evidence presented above are individually inconclusive, we venture to suggest that Hadimopanella and Utahphospha were fossil skeletal units exclusively of ectodermal origin which may have pertained to early relatives of the ascidians. Thus, cone-shaped specimens of Utahphospha sequina could be fused hard parts located superficially in the tunic of a possibly solitary form, instead of representing the remains of reproductive cysts as suggested by Müller \& Miller (1976, p. 109). The fusion between the sclerites in this taxon is apparently due to the development of hard substance in the inter-sclerite wall, between and beneath the sclerites. By the time of fusion, the sclerites had already acquired their final size and shape. It has been demonstrated above that formation of such a hard substance also occurred in the inter-sclerite wall, peripherally to fully formed sclerites, in Hadimopanella apicata (Figs 5,6) but there is no evidence to suggest that it was developed to an extent similar to that seen in Utahphospha sequina and $U$. cassiniana.

Interpretation of Hadimopanella and Utahphospha as early Palaeozoic relatives of the ascidians must necessarily remain tentative until further information becomes available. However, as possible representatives of a palaeontologically little-known group with only slight potential for fossilisation, this is a fate to be shared with other problematic fossils from Palaeozoic strata which have been variously assigned to the Urochordata: Permosoma tunicata Jaekel, 1918; Gochtia rete Eisenack, 1968; Palaeobotryllus taylori Müller, 1977 and an un-named alleged tunicate from the lower Cambrian of China (Jaekel, 1918; Eisenack, 1968; Müller, 1977; Zhang, 1985). If our interpretation of Hadimopanella and Utahphospha gains confirmation, it will also imply that the Urochordata diverges radically from the Vertebrata among the Euchordata with respect to the trend in bioanorganic evolution of hard substances. The Euchordata includes the Cephalochordata and the Vertebrata which are known in the form of the cephalochordate Pikaia gracilens (Conway Morris \& Whittington, 1979) and some of the so-called Anatolepis material figured by Repetski (1978) from the Middle and Upper Cambrian, respectively. This difference would suggest considerably greater evolutionary separation of the Urochordata and the Euchordata and a geologically-speaking much earlier split between the two groups than seems to be assumed 
by most writers. The suggestion, however, is in perfect accord with the recent evaluation by Jarvik (1988) of Urochordata - Euchordata phylogenetic interrelationships.

\section{Dansk sammendrag}

Det præsenterede nye materiale godtgør, at de mikroskopiske, fosfatiske skleriter af slægten Hadimopanella, som tidligere er rapporteret fra det vestlige Nordgrønland, optræder almindeligt i nedre kambriske aflejringer tilhørende Aftenstjernes $\emptyset$ og Henson Gletscher Formationerne fra sydlige Peary Land i øst til Nyeboe Land i vest. Hadimopanella forekommer som element i faunaer omfattende både mikro- og makrofossiler.

Foruden typiske Hadimopanella apicata skleriter omfatter det nye materiale endnu en sklerit-type, der påminder noget om Hadimopanella antarctica nyligt beskrevet fra sydpolar området.

Mere signifikant dokumenterer materialet væsentlige nye træk af Hadimopanella skleriternes histologiske bygning og ultrastruktur. Nogle af disse træk indicerer, at skleriterne ontogenetisk set er rent ektodermalt deriverede. Andre træk leder til tydning af skleriternes oprindelige indbyrdes placering og distribution. Tydningens sandsynlighed støttes starkt af nye fund, der viser ansamlinger af Hadimopanella antarctica skleriter bevarede $i$ tilsyneladende nasten uforstyrrede indbyrdes positioner.

Materialet dokumenterer også tilstedvarelsen af mineralisering dannet in vivo, perifert for skleriterne, efter at disse ontogentisk set var fuldt udviklede. Herved sandsynliggøres antagelsen om nært slægtskab til den øvre kambrisk - nedre ordoviciske slægt Utahphospha, hvor skleriterne gennem intersklerit mineralisering er forenede i større komplekser, der hos Utahphospha sequina har bægeragtig form.

Histologisk viser Hadimopanella skleriterne ingen overbevisende ligheder med dermalskelet-elementer fra ordoviciske vertebrater. Der er heller ikke ligheder med materiale tilskrevet den stærkt omdiskuterede kambro-ordoviciske Anatolepis.

Hadimopanella og Utahphospha skleriterne sammenlignes indgående med de ligeledes ektodermale skeletdannelser spikler, der forekommer i kappen hos en rakke recente og fossile slægter og arter af kolonidannende søpunge (Ascidiacea, Tunicata). Især spiklerne hos slægten Cystodytes viser bemærkelsesværdige morfologiske ligheder med Hadimopanella apicata skleriterne. Der redegøres for ligheder og forskelle. Mange af de træk, hvor spiklerne tilsyneladende afviger væsentligt fra skleriterne, kan forklares som rent sekundære, opstået i forbindelse med de gennemgribende specialiseringer, der præger kappen, som den kendes hos recente tunikater. I sarlig grad galder det kappen hos de kolonidannende ascidier inklusive Cystodytes.

På grundlag af sammenligningerne gives en tentativ interpretation af Hadimopanella og Utahphospha som fossile, ektodermale skeletdannelser hidrørende fra tidlig palæozoiske repræsentanter for sækdyrene: klassen Urochordata.

Hadimopanella og Utahphospha skleriternes oprindelige bioanorganiske komponent var sandsynligvis en variant af apatit, medens aragonit og vaterit er de mineraltyper, der kendes fra recente ascidiers spikler. Dette skal næppe tillægges megen betydning for så vidt angår interpretationen af Hadimopanella og Utahphospha som urochordat repræsentanter. Forskellen kan ses som endnu et eksempel på det kendte fænomen: Fosfatisk mineraliserede hård-væev forekommer indenfor en st $\emptyset r r e$ mangfoldighed af højere taxa fra kambriske end fra yngre phanerozoiske aflejringer. Den fremskridende substituering med karbonat mineralisering for fosfatisk er observeret hos mange grupper af organismer $\mathrm{og}$ må betragtes som den vigtigste grundlæggende tendens, der endnu kan påvises generelt indenfor evolutionen af hård-væv.

Forskellen kan måske også belyse et andet interessant aspekt. Hvis Hadimopanella og Utahphospha systematisk set er korrekt interpreterede, så er Urochordata med hensyn til bioanorganisk hård-vævs evolution radikalt forskellige fra Vertebrata, hvilket kun kan betyde, at Urochordata og Euchordata (=Cephalochordata + Vertebrata) evolutionmæssigt står ganske fjernt fra hinanden.

Acknowledgements. We thank Gretchen Lambert for useful advice and for supplying specimens of Cystodytes lobatus for study. John Repetski and Klaus Müller kindly provided illustrations of Utahphospha acknowledged in the text, which are reproduced with permission from the Paleontological Society and the Lethaia Foundation, respectively. Simon Conway Morris and $\mathrm{M}$. Paul Smith are thanked for comments to the manuscript. Professor T. Ørvig permitted examination of Spitsbergen Anatolepis then on loan to him from the Paleontologisk Museum, Oslo. Niels $\mathrm{H}$. Larsen prepared the samples in GGU and took scanning electron micrographs using facilitics provided by the Laboratory for Electron Microscopy, Geological Central Institute, University of Copenhagen. Bodil Sikker Hansen and Bente Thomas drew the figures; Poul Schiøler assisted with photomicroscopy. S. E. B.-A. acknowledges support from the Danish Natural Science Research Council (SNF grant 781-5645) making it possible for him to attend the "Symposium on early vertebrate studies and related problems in evolutionary biology" in Beijing (October 1987). J. S. P. publishes with permission from the Director, Geological Survey of Greenland.

Location of material: MGUH, Geologisk Museum, Copenhagen; UB, Rhienische Friedrich-Wilhelms-Universität, Bonn: USNM, National Museum of Natural History, Washington D.C.

\section{References}

Bendix-Almgreen, S. E. 1983: Carcharodon megalodon from Upper Miocene of Denmark, with comments on elasmobranch tooth enameloid: coronoïn. Bull. geol. Soc. Denmark 32, 1-32.

Bengtson, S. 1977: Early Cambrian button-shaped phosphatic microfossils from the Sibirian Platform. Palaeontology 20, 751-762.

Berg-Madsen, V. 1985: Middle Cambrian biostratigraphy, fauna and facies in southern Balto-scandia. Acta Univ. Upsal. Abstr. Upps. Dissert. Fac. Sci. 781, 1-37.

Blaker, M. R. 1986: Notes on the trilobite faunas of the Henson Gletscher Formation (Lower and Middle Cambrian) of central North Greenland. Rapp. Gronlands geol. Unders. $132,75-73$.

Bockelie, T. G. \& Fortey, R. A. 1976: An early Ordovician vertebrate. Nature $260,36-38$.

van den Boogaard, M. 1983: The occurrence of Hadimopanella oezgueli Gedik in the Lancara Formation in NW Spain. Proc. K. ned. Akad. Wet. B, 86, 331-341.

Brien, P. 1948: Embranchement des Tuniciers: Morphologie et reproduction. In Grassé, P.-P. (edit.): Traité de Zoologie 11, 553-930. Paris: Masson \& Cie.

Briggs, D. E. G. \& Fortey, R. A. 1982: The cuticle of aglaspid arthropods, a red-herring in the early history of the vertebrates. Lethaia 15, 25-29.

Bryant, W. L. 1936: A study of the oldest known vertebrates, 
Astraspis and Eriptychius. Proc. Amer. Phil. Soc. 76, 409427.

Bushinsky, G. I. 1935: Structure and origin of phosphorites in the USSR. Jour. Sed. Pet. 5, 81-92.

Conway Morris, S. \& Whittington, H. B. 1979: The animals of the Burgess Shale. Scient. Amer. 241, 110-120.

Dawes, P. R. \& Peel, J. S. 1984: Biostratigraphic reconnaissance in the Lower Palaeozoic of western North Greenland. Rapp. Gronlands geol. Unders. 121, 19-51.

Denison, R. H. 1967: Ordovician vertebrates from western United States. Fieldiana Geol. 16, 131-192.

Dzik, J. 1986: Chordate affinities of the conodonts. In Hoffmann, A. \& Nitecki, M. H. (edit.) Problematic fossil taxa, 240-254. New York: Oxford Univ. Press.

Eisenack, A. 1968: Problematika aus dem baltischen Ordovicium und Silur. Neues Jahrb. Geol. Paläont. Abh. 131, 305-309.

Gazdzicki, A. \& Wrona, R. 1986: Polskie badania paleontologiczenie w Antarktyce Zachodniej (1986). Przeglad geologiczny 1986, 11, 609-617.

Gedik, I. 1977: Orta Toroslar'da konodont biostratigrafisi. Bull. Türk. Jeol. Kurumu 20, 35-48.

Gedik, I. 1981: Hadimopanella Gedik, 1977 'nin stratigrafik dagilimi ve mikroyapisi konusunda bazi gözlemler. Karadeniz Tek. Univ. Yer Bilimleri Dergisi, Jeol. 1(2), 159-163.

Glas, J.-E. 1962: Studies of ultrastructure of dental enamel. VI. Crystal chemistry of shark's teeth. Odont. Revy 13(4), 315-326.

Gross, W. 1967: Über Thelodontier-Schuppen. Palaeontographica A, 127, 1-67.

Henriksen, N. 1987: Systematic geological mapping in 1985 in central and western North Greenland. Rapp. Grønlands geol. Unders. 133, 5-12.

Higgins, A. K., Ineson, J. R., Peel, J. S., Surlyk, F. \& Sønderholm, M.: in press. The Franklinian basin in North GreenIand. In Trettin, H. P. (edit.) The Innuitian region. The Geology of North America vol. E. Ottawa: Geol. Surv. Canada.

Hinz, 1. 1987: The Lower Cambrian microfauna of Comley and Rushton, Shropshire/England. Palaeontographica A, 198, 41-100.

Huus, J., Ihle, I. E. W., Lohmann, H. \& Neumann, G. 1956: Tunicata. In Krumbach, T. (edit.) Handbuch der Zoologie 15, 3-771. Berlin: Walter de Greyter \& Co.

Ineson, J. R. \& Peel, J. S. 1987: Cambrian platform - outer shelf relationships in the Nordenskiold Fjord region, central North Greenland. Rapp. Grønlands geol. Unders. 133, 13-26.

Ineson, J. R. \& Peel, J. S. in press: Cambrian shelf stratigraphy of North Greenland. Bull. Grønlands geol. Unders.

Jaekel, O. 1918: Über fragliche Tunicaten aus dem Perm Siziliens. Paläont. Z. 2, 66-74.

Jope, M. 1980: Phylogenetic information derivable from fossil brachiopods. In Hare, P. E., Hoering, T. C. \& King, K. (edit.) Biogeochemistry of amino acids, 83-94. New York: John Wiley \& Sons.

Jarvik, E. A. V. 1988: The early vertebrates and their forerunners. L'Evolution dans sa réalité et ses diverses modalités, 35-63. Paris: Fondation Singer-Polignac \& Masson.

Lafargue, F. \& Kniprath, E. 1978: Formation des spicules de Didemnidae (ascidian composées). 1. L'apparition des spicules chez l'oozoïde après la métamorphose. Mar. Biol., 45, 175-184.

Lambert, G. 1979: Early post-metamorphic growth, budding and spicule formation in the compound ascidian Cystodytes lobatus. Biol. Bull. 157, 464-477.

Lowenstam, H. A. 1980: Bioinorganic constituents of hard parts. In Hare, P. E., Hoering, T. C. \& King, K. (edit.) Biogeochemistry of amino acids, 3-16. New York: John Wiley \& Sons.
Lowenstam, H. A. \& Abbott, D. P. 1975: Vaterite: a mineralisation product of the hard tissues of a marine organism (Ascidiacea). Science 188, 363-365.

Märss, T. 1988: Early Palaeozoic hadimopanellids of Estonia and Kirgizia (USSR). Toimetised Eesti NSV Tead. Akad. Geol. 37, 10-17.

Mathews, M. B. 1975: Connective tissue. Macromolecular structure and evolution. In Kleinzeller, A., Springer, G. F. \& Wittmann, H. G. (edit.) Molecular biology, biochemistry and biophysics 19,318 pp. Berlin, Heidelberg \& New York: Springer Verlag.

McConnell, D. 1979: Biogeochemistry of phosphate minerals. In Trudinger, P. A. \& Swaine, D. J. (edit) Biogeochemical cycling of mineral-forming elements, 163-204. Amsterdam: Elsevier Scientific Publishing Comp.

Missarzhevsky, V. V. 1983: Subdivision and correlation of the Precambrian-Cambrian boundary sequences based on certain groups of skeletal organisms. Internat. Geol. Rev. 25, 745-759.

Monniot, F. 1970: Les spicules chez les Tuniciers aplousobranches. Arch. Zool. exp. gén. 111, 303-311.

Monniot, F. \& Buge, E. 1971: Les spicules d'ascidies fossiles et actuelles. Ann. Paléont. Invertébrés 58, 93-105.

Moss, M. L. 1968: The origin of vertebrate calcified tissues. In $\emptyset_{\text {rvig, }} \mathrm{T}$. (edit.) Current problems of lower vertebrate phylogeny. Proc. Fourth Nobel Symp., 359-371. Stockholm: Almquist \& Wiksell.

Müller, K. J. 1977: Palaeobotryllus taylori from the Upper Cambrian of Nevada - a probable ascidian. Lethaia 10 , 107-118.

Müller, K. J. \& Miller, J. F. 1976: The problematic microfossil Utahphospha from the Upper Cambrian of the western United States. Lethaia 9, 391-395.

Ørvig, T. 1958: Pycnaspis splendens, new genus, new species, a new ostracoderm from Upper Ordovician of North America. Proc. U. S. natn. Mus. 108, 1-23.

Ørvig, T. 1965: Palaeohistological notes. 2. Certain comments on the phyletic significance of acellular bone tissue in early lower vertebrates. Ark. Zool. (ser. 2) 16, 551-556.

$\emptyset$ rvig, T. 1967: Phylogeny of tooth tissues: evolution of some calcified tissues in early vertebrates. In Miles, A. E. W. (edit) Structural and chemical organization of teeth. 1. 45110. New York \& London: Academic Press.

$\emptyset$ rvig, T. 1968: The dermal skeleton; general considerations. In $\emptyset_{\text {rvig, }} \mathrm{T}$. (edit) Current problems in lower vertebrate phylogeny. Proc. Fourth Nobel Symp. 373-397. Stockholm: Almquist \& Wiksell.

Ørvig, T. 1976: Palaeohistological notes. 4. The interpretation of osteodentine, with remarks on the dentition in the Devonian dipnoan Griphognathus. Zool. Scr. 5, 79-96.

$\emptyset$ rvig, T. 1977: A survey of odontodes ('dermal teeth') from developmental, structural, functional, and phyletic points of view. In Andrews, M. S., Miles, R. S. \& Walker, A. D. (edit). Problems in vertebrate evolution, 53-75. London: Linnean Soc. Symp. Ser. No. 4.

Ørvig, T. 1978: Microstructure and growth of the dermal skeleton in fossil actinopterygian fishes: Nephrotus and $\mathrm{Col}$ obodus, with remarks on the dentition in other forms. Zool. Scr. 7, 297-326.

Ørvig, T. 1980: Histologic studies of ostracoderms, placoderms and fossil elasmobranchs. 4. Ptyctodontid tooth plates and their bearing on holocephalan ancestry: the conditions of Ctenurella and Ptyctodus. Zool. Scr. 9, 219-239.

Palmer, A. R. \& Peel, J. S. 1979: New Cambrian faunas from Peary Land, eastern North Greenland. Rapp. Grønlands geol. Unders. 91, 29-36.

Peel, J. S. 1974: Lower Cambrian fossils from Nyeboe Land, North Greenland fold belt. Rapp. Grønlands geol. Unders. 65, 17 (only).

Peel, J. S. 1979: Anatolepis from the Early Ordovician of East 
Greenland - not a fishy tail. Rapp. Grønlands geol. Unders. 91, 111-115.

Peel, J. S. \& Blaker, M. R. 1988: The small shelly fossil Mongolitubulus from the Lower Cambrian of central North Greenland. Rapp. Gronlands geol. Unders. 137, in press.

Peel, J. S. \& Larsen, N. H. 1984: Hadimopanella apicata from the Lower Cambrian of western North Greenland. Rapp. Gronlands geol. Unders. 121, 89-96.

Reif, W.-E. 1979: Structural convergences between enameloid of actinopterygian teeth and of shark teeth, Scanning Electron Microsc. 2, 546-554.

Repetski, J. E. 1978: A fish from the Upper Cambrian of North America. Science 200, 529-531.

Repetski, J. E. 1981: An Ordovician occurrence of Utahphospha Müller \& Miller. J. Paleont. 55, 395-400.

Rhodes, F. H. T. \& Bloxam, T. W. 1971: Phosphatic organisms in the Paleozoic and their evolutionary significance. Proc. North Amer. Paleont. Conv., Pt. K. 1485-1513.

Schmidt, W. J. 1924: Die Bausteine des Tierkörpers in polarisiertem Lichte. 528 pp. Bonn: Verlag Friederich Cohen.
Smith, M. J. 1970: The blood cells and tunic of the ascidian Halocynthia aurantium (Pallas). 1. Hematology, tunic morphology, and partition of cells between blood and tunic. Biol. Bull. 138, 354-378.

Stievenart, J. 1971: Recherches sur la morphologie et étude histochimique de la tunique d'Halocynthia papillosa Gun. (Ascidie Stolidobranche). Ann. Soc. R. Zool. Belg. 101, 25-56.

Thompson, D. \& Plotnick, R. E. 1981: Cambrian vertebrates: are they arthropods? Geol. Soc. Am. Abstracts with Programs 13(7), 566 (only).

Van Name, W. G. 1945: The North and South American ascidians. Bull. Am. Mus. Natl. Hist. 84, 1-476.

Wrona, R. 1982: Early Cambrian phosphatic microfossils from southern Spitsbergen (Hornsund region). Palaeont. Polon. 43, 9-16.

Wrona, R. 1987: Cambrian microfossil Hadimopanella from glacial erratics in West Antarctica. Palaeont. Polon. 49, $37-48$.

Zhang, A. 1985 Discovery of fossil tunicates at the initial stage of the Cambrian. Kexue Tongbao 30, 1643-1647. 